\title{
Article \\ Support Effects on the Activity of Ni Catalysts for the Propane Steam Reforming Reaction
}

\author{
Aliki Kokka ${ }^{1}$, Athanasia Petala ${ }^{2}$ and Paraskevi Panagiotopoulou ${ }^{1, *}$ \\ 1 School of Chemical and Environmental Engineering, Technical University of Crete, 73100 Chania, Greece; \\ akokka@isc.tuc.gr \\ 2 Department of Chemical Engineering, University of Patras, 26504 Patras, Greece; \\ natpetala@chemeng.upatras.gr \\ * Correspondence: ppanagiotopoulou@isc.tuc.gr; Tel.: +30-28210-37770
}

Citation: Kokka, A.; Petala, A.; Panagiotopoulou, P. Support Effects on the Activity of Ni Catalysts for the Propane Steam Reforming Reaction. Nanomaterials 2021, 11, 1948. https:// doi.org/10.3390/nano11081948

Academic Editors: Nikolaos Dimitratos and Alberto Villa

Received: 30 June 2021

Accepted: 27 July 2021

Published: 28 July 2021

Publisher's Note: MDPI stays neutral with regard to jurisdictional claims in published maps and institutional affiliations.

Copyright: (C) 2021 by the authors. Licensee MDPI, Basel, Switzerland. This article is an open access article distributed under the terms and conditions of the Creative Commons Attribution (CC BY) license (https:// creativecommons.org/licenses/by/ $4.0 /)$.

\begin{abstract}
The catalytic performance of supported Ni catalysts for the propane steam reforming reaction was investigated with respect to the nature of the support. It was found that $\mathrm{Ni}$ is much more active when supported on $\mathrm{ZrO}_{2}$ or $\mathrm{YSZ}$ compared to $\mathrm{TiO}_{2}$, whereas $\mathrm{Al}_{2} \mathrm{O}_{3}$ - and $\mathrm{CeO}_{2}$-supported catalysts exhibit intermediate performance. The turnover frequency (TOF) of $\mathrm{C}_{3} \mathrm{H}_{8}$ conversion increases by more than one order of magnitude in the order $\mathrm{Ni} / \mathrm{TiO}_{2}<\mathrm{Ni} / \mathrm{CeO}_{2}<\mathrm{Ni} / \mathrm{Al}_{2} \mathrm{O}_{3}<\mathrm{Ni} / \mathrm{YSZ}<\mathrm{Ni} / \mathrm{ZrO}_{2}$, accompanied by a parallel increase of the selectivity toward the intermediate methane produced. In situ FTIR experiments indicate that $\mathrm{CH}_{\mathrm{x}}$ species produced via the dissociative adsorption of propane are the key reaction intermediates, with their hydrogenation to $\mathrm{CH}_{4}$ and/or conversion to formates and, eventually, to $\mathrm{CO}$, being favored over the most active $\mathrm{Ni} / \mathrm{ZrO}_{2}$ catalyst. Long term stability test showed that $\mathrm{Ni} / \mathrm{ZrO}_{2}$ exhibits excellent stability for more than $30 \mathrm{~h}$ on stream and thus, it can be considered as a suitable catalyst for the production of $\mathrm{H}_{2}$ via propane steam reforming.
\end{abstract}

Keywords: propane steam reforming; $\mathrm{H}_{2}$ production; $\mathrm{Ni} ; \mathrm{TiO}_{2} ; \mathrm{CeO}_{2} ; \mathrm{YSZ} ; \mathrm{ZrO}_{2} ; \mathrm{Al}_{2} \mathrm{O}_{3} ;$ drifts

\section{Introduction}

The high energy efficiency of fuel cells has drawn considerable attention toward the development of hydrogen production technologies. Hydrogen can be produced from fossil fuels either via hydrocarbon pyrolysis or hydrocarbon reforming processes including steam reforming, partial oxidation or autothermal reforming [1-5]. Biomass processes consisting of biological (bio-photolysis, dark fermentation, photo fermentation) and thermochemical (pyrolysis, gasification, combustion, liquefaction) methods as well as water splitting processes such as electrolysis, thermolysis or photolysis can be alternatively applied for the production of $\mathrm{H}_{2}$ from renewable energy sources [2,6]. However, the latter approaches are facing some major obstacles mostly related to high cost and low $\mathrm{H}_{2}$ yields. Currently, steam reforming of light hydrocarbons, including natural gas, ethane, propane, butane and liquified petroleum gas (LPG), are considered among the most promising and economical routes for hydrogen production [7]. Propane, which is the main component of LPG, has many advantages such as high energy density, compressibility to a transportable liquid at normal temperature and well-developed infrastructure which enable its use worldwide [8-10]. Moreover, propane can be stored and transferred as LPG through a wide distribution network or in high pressure cylinders in order to be supplied in remote places (e.g., agricultural, inaccessible or camping areas) or for domestic uses (e.g., households) [3,7].

Under propane steam reforming conditions, the water-gas shift reaction occurs simultaneously at low temperatures contributing to $\mathrm{H}_{2}$ and $\mathrm{CO}_{2}$ production, whereas $\mathrm{CO} / \mathrm{CO}_{2}$ methanation may also run in parallel yielding $\mathrm{CH}_{4}$ and $\mathrm{H}_{2} \mathrm{O}$. Methane can be also formed via hydrogenation of $\mathrm{CH}_{x}$ species derived by the dissociative adsorption of propane on the catalyst surface or through propane decomposition accompanied by ethylene production. In certain cases, the $\mathrm{C}_{2} \mathrm{H}_{4}, \mathrm{CH}_{4}$ and $\mathrm{CO}$ thus produced are further decomposed 
leading to the formation of coke on the catalyst surface and consequently, to its progressive deactivation $[11,12]$.

Supported noble metal $(\mathrm{Rh}, \mathrm{Ru}, \mathrm{Pt}, \mathrm{Pd})$ catalysts have been proposed to efficiently catalyze the production of $\mathrm{H}_{2}$ via propane steam reforming exhibiting high resistance to coke formation $[3,11,13,14]$. However, the high cost and low availability of noble metals are major drawbacks restricting their use in practical applications [15-17]. Noble metals can be replaced by nickel, which is less expensive and able to convert propane with high $\mathrm{H}_{2}$ yields. However, $\mathrm{Ni}$ is susceptible to coke formation and particles sintering considered to be responsible for catalyst deactivation $[5,10,17]$. The lifetime of Ni-based catalysts can be improved by optimization of the reaction conditions, catalyst promotion, improvement of the catalyst synthesis method as well as by the proper selection of the support $[3,9,10,12,16,18,19]$.

Regarding the support material, it has been proposed that metal oxides characterized by high oxygen storage capacity, such as $\mathrm{CeO}_{2}, \mathrm{YSZ}, \mathrm{TiO}_{2}, \mathrm{ZrO}_{2}$ or $\mathrm{CeO}_{2}-\mathrm{ZrO}_{2}$, are able to suppress carbon deposition through the participation of their lattice oxygen in carbon removal $[3,16]$. Moreover, Ni catalysts supported on metal oxides or promoted metal oxides, which favor steam adsorption and mobility of surface hydroxyls, have been found to facilitate coke gasification $[17,20]$.

Metal-support interactions have been also reported to impose a dramatic effect on both carbon deposition and metal particles sintering under conditions of hydrocarbons reforming $[5,21,22]$. It was demonstrated that stronger interactions between $\mathrm{Ni}$ and $\mathrm{MgAl}_{2} \mathrm{O}_{4}$ support resulted in high $\mathrm{Ni}$ dispersion and inhibition of the formation of large $\mathrm{Ni}$ clusters [22], whereas weak interactions between $\mathrm{Ni}$ and $\mathrm{SiO}_{2}$ carrier were found to accelerate sintering and coke formation [21].

Therefore, the economic viability and practical applicability of $\mathrm{H}_{2}$ production via propane steam reforming may be facilitated by the development of efficient $\mathrm{Ni}$ catalysts supported on suitable metal oxides, which will be able to possess both high activity and resistance against carbon deposition and particles sintering to realize economically viable reforming processes. In the present study the effect of the nature of the support $\left(\mathrm{TiO}_{2}, \mathrm{CeO}_{2}\right.$, $\mathrm{Al}_{2} \mathrm{O}_{3}, \mathrm{YSZ}, \mathrm{ZrO}_{2}$ ) on the activity and selectivity of Ni-based catalysts for the propane steam reforming reaction was investigated. Mechanistic aspects related to the support influence on the reaction pathway were also studied and are discussed.

\section{Materials and Methods}

\subsection{Catalyst Preparation and Characterization}

The wet impregnation method was applied to prepare $\mathrm{Ni}(5 \mathrm{wt} . \%)$ catalysts supported on commercial metal oxide powders by using an aqueous solution of $\mathrm{Ni}\left(\mathrm{Ni}\left(\mathrm{NO}_{3}\right)_{2} \cdot 6 \mathrm{H}_{2} \mathrm{O}\right)$ as the metal precursor salt. The commercial metal oxide carriers were used as received and were (a) activated aluminum oxide $\left(\mathrm{Al}_{2} \mathrm{O}_{3}\right)$, catalyst support, $99 \%$ (metals basis) (Alfa Aesar, Kandel, Germany), (b) AEROXIDE ${ }^{\circledR} \mathrm{TiO}_{2} \mathrm{P} 25\left(\mathrm{TiO}_{2}\right)$ (Evonik Industries AG, Essen, Germany), (c) cerium (IV) oxide $\left(\mathrm{CeO}_{2}\right)$, nanopowder, $99.5 \%$ min (Alfa Aesar, Kandel, Germany), (d) yttria-stabilized zirconia (YSZ) (8Y-SZ, Tosoh, Amsterdam, The Netherlands) and (e) zirconium (IV) oxide $\left(\mathrm{ZrO}_{2}\right) 99 \%$ (metal basis) (Alfa Aesar, Kandel, Germany). The resulting materials were dried at $110^{\circ} \mathrm{C}$ for $24 \mathrm{~h}$ followed by reduction at $400^{\circ} \mathrm{C}$ under $\mathrm{H}_{2}$ flow for $2 \mathrm{~h}$. The selection of reducing Ni catalysts at $400{ }^{\circ} \mathrm{C}$ for $2 \mathrm{~h}$ was based on previous studies which indicated that under these reducing conditions nickel oxide species are able to be completely converted to metallic nickel [23-25].

The X-ray diffraction patterns of the catalysts were recorded using an X-ray powder diffractometer (A Brucker D8 Advance instrument, Bruker, Karlsruhe, Germany) using $\mathrm{Cu}$ $K_{a}$ radiation $(\lambda=0.15406 \mathrm{~nm}, 40 \mathrm{kV}, 40 \mathrm{~mA})$ and a scan rate of $0.025^{\circ} / \mathrm{s}$ over a range of $2 \theta$ between 20 and $80^{\circ}$. The diffraction pattern was identified by comparison with those 
supplied from the JCPDS data base, whereas the primary crystallite size of $\mathrm{M}_{\mathrm{x}} \mathrm{O}_{\mathrm{y}}\left(\mathrm{d}_{\mathrm{MxOy}}\right)$ was estimated according to Scherrer's equation:

$$
\mathrm{d}_{\mathrm{M}_{\mathrm{x}} \mathrm{O}_{\mathrm{y}}}=\frac{0.9 \cdot \lambda}{\mathrm{B} \cdot \cos \theta}
$$

where $\theta$ is the angle of diffraction corresponding to the peak broadening, $B$ is the fullwidth at half maximum intensity (in radians) and $\lambda=0.15406 \mathrm{~nm}$ is the $X$-ray wavelength corresponding to $\mathrm{Cu} K_{a}$ radiation.

The specific surface area (SSA) of the supported $\mathrm{Ni}$ catalysts were measured by $\mathrm{N}_{2}$ adsorption at $77 \mathrm{~K}$ (B.E.T. technique) using a Gemini III 2375 instrument (Micromeritics, Norcross, GA, USA). Carbon monoxide chemisorption measurements at $25^{\circ} \mathrm{C}$ were applied for the determination of $\mathrm{Ni}$ dispersion and mean particle size using a modified Sorptomatic 1900 apparatus (Fisons Instruments, Glaskow, UK) and assuming a CO:Me stoichiometry of 1:1, an atomic surface area of $6.5 \AA^{2}$ and spherical particles. CO chemisorption measurements were used instead of $\mathrm{H}_{2}$ chemisorption in order to avoid overestimation of $\mathrm{Ni}$ dispersion due to hydrogen spillover effects, which have been previously found to occur over supported Ni catalysts [26,27]. Nickel particle size was calculated according to the following equation:

$$
\mathrm{d}_{\mathrm{Ni}}=\frac{60000}{\rho_{\mathrm{Ni}} \cdot \mathrm{S}_{\mathrm{Ni}}}[\AA]
$$

where $\mathrm{d}_{\mathrm{Ni}}$ is the mean crystallite diameter, $\rho_{\mathrm{Ni}}\left(=8.9 \mathrm{~g} \cdot \mathrm{cm}^{-3}\right)$ is the density of $\mathrm{Ni}$ and $\mathrm{S}_{\mathrm{Ni}}$ $\left[\mathrm{m}^{2} / \mathrm{g}_{\mathrm{Ni}}\right]$ is the surface area per gram of $\mathrm{Ni}$.

Transmission electron microscopy (TEM) images were obtained with a JEM-2100 system (JEOL, Akishima, Tokyo, Japan) operated at $200 \mathrm{kV}$ (point resolution $0.23 \mathrm{~nm}$ ) using an Erlangshen CCD Camera (Model 782 ES500W, Gatan Inc., Pleasanton, CA, USA). Samples were dispersed in water and spread onto a carbon-coated copper grid (200 mesh). Details related to the equipment and procedures used for catalyst characterization have been described in detail elsewhere [28].

\subsection{Catalytic Performance Tests and Kinetic Measurements}

The catalytic performance of the synthesized materials was studied in a tubular fixed-bed quartz reactor under atmospheric pressure using an apparatus which has been described in detail elsewhere [11]. The reaction conditions were as follows: temperature range $400-750{ }^{\circ} \mathrm{C}, \mathrm{H}_{2} \mathrm{O} / \mathrm{C}=3.25$, and gas hourly space velocity (GHSV) $=55,900 \mathrm{~h}^{-1}$. The reactor was loaded with $150 \mathrm{mg}$ of catalyst (particle diameter: $0.15<\mathrm{d}_{\mathrm{p}}<0.25 \mathrm{~mm}$ ) and placed in an electric furnace, where it was reduced in situ at $300{ }^{\circ} \mathrm{C}$ for $1 \mathrm{~h}$ under $50 \% \mathrm{H}_{2} / \mathrm{He}$ flow $\left(60 \mathrm{~cm}^{3} \mathrm{~min}^{-1}\right)$ to ensure that the $\mathrm{Ni}$ exists in its metallic phase prior to catalytic performance tests. Catalyst reduction was followed by heating at $750{ }^{\circ} \mathrm{C}$ under $\mathrm{He}$ and subsequent switch of the flow to the feed stream consisted of $4.5 \% \mathrm{C}_{3} \mathrm{H}_{8}$ $+0.15 \% \mathrm{Ar}+44 \% \mathrm{H}_{2} \mathrm{O}$ (He balance). Argon was used as internal standard in order to account for the volume change. Water was fed through an HPLC pump (LD Class Pump, TELEDYNE SSI, PA, USA) into a vaporizer maintained at $180^{\circ} \mathrm{C}$ and mixed with the gas stream coming from mass-flow controllers. A condenser immersed in an ice bath was placed at the exit of the reactor to condensate water prior to introduction of the gas stream to the analysis system. Reaction gases $\left(\mathrm{He}, 30 \% \mathrm{C}_{3} \mathrm{H}_{8}-1 \% \mathrm{Ar} / \mathrm{He}, \mathrm{H}_{2}\right)$ are supplied from high-pressure gas cylinders (Buse Gas, Bad Hönningen, Germany) and are of ultrahigh purity. Measurements of reactants' and products' concentrations were obtained by stepwise decreasing temperature up to $400{ }^{\circ} \mathrm{C}$. The effluent from the reactor was analyzed using two gas chromatographs (Shimadzu, Kyoto, Japan) which were connected in parallel. The procedure used for gas phase analysis was described in our previous study [11]. The conversion of propane $\left(\mathrm{X}_{\mathrm{C}_{3} \mathrm{H}_{8}}\right)$ was calculated using the following expression:

$$
\mathrm{X}_{\mathrm{C}_{3} \mathrm{H}_{8}}=\frac{[\text { Carbon }]_{\text {total,out }}}{[\text { Carbon }]_{\text {total, out }}+\left[\mathrm{C}_{3} \mathrm{H}_{8}\right]_{\text {out }}} \times 100
$$


where [Carbon $]_{\text {total,out }}$ is the sum of the concentrations of all carbon containing products:

$$
[\text { Carbon }]_{\text {total }, \text { out }}=\frac{[\mathrm{CO}]+\left[\mathrm{CO}_{2}\right]+\left[\mathrm{CH}_{4}\right]}{3}+2 \times \frac{\left[\mathrm{C}_{2} \mathrm{H}_{4}\right]+\left[\mathrm{C}_{2} \mathrm{H}_{6}\right]}{3}
$$

Selectivity toward reaction products containing carbon was defined using Equation (5). The factor $n$ corresponds to the number of carbon atoms in the corresponding molecule (e.g., for $\mathrm{CO}$ is 1 , for $\mathrm{C}_{2} \mathrm{H}_{4}$ is 2 etc.):

$$
\mathrm{S}_{\mathrm{Cn}}=\frac{\left[\mathrm{C}_{\mathrm{n}}\right] \times \mathrm{n}}{3 \times[\text { Carbon }]_{\text {total,out }}} \times 100
$$

Selectivity toward hydrogen production was defined as the concentration of hydrogen produced divided with the concentration of all products containing hydrogen according to Equation (6). The factor $\mathrm{m}$ represents the number of hydrogen atoms in the corresponding molecule (e.g., for $\mathrm{CH}_{4}$ and $\mathrm{C}_{2} \mathrm{H}_{4}$ is 4 ).

$$
\mathrm{S}_{\mathrm{H}_{2}}(\%)=\frac{\left[\mathrm{H}_{2}\right]}{\left[\mathrm{H}_{2}\right]+\mathrm{m} / 2 \times\left[\mathrm{C}_{\mathrm{n}} \mathrm{H}_{\mathrm{m}}\right]} \times 100
$$

The intrinsic reaction rates for propane steam reforming reaction were measured for low propane conversions $\left(\mathrm{X}_{\mathrm{C}_{3} \mathrm{H}_{8}}<10 \%\right)$ by varying $\mathrm{W} / \mathrm{F}$ using the following expression:

$$
\mathrm{R}_{\mathrm{C}_{3} \mathrm{H}_{8}}=\frac{\left[\mathrm{C}_{3} \mathrm{H}_{8}\right]_{\text {in }} \cdot \mathrm{F}_{\text {in }}-\left[\mathrm{C}_{3} \mathrm{H}_{8}\right]_{\text {out }} \cdot \mathrm{F}_{\text {out }}}{\mathrm{W}} \times 100
$$

where $\mathrm{R}_{\mathrm{C} 3 \mathrm{H} 8}$ is the molar rate of $\mathrm{C}_{3} \mathrm{H}_{8}$ consumption ( $\mathrm{mol} \mathrm{s}^{-1} \mathrm{~g}_{\text {cat }}{ }^{-1}$ ), $\left[\mathrm{C}_{3} \mathrm{H}_{8}\right]_{\text {in }},\left[\mathrm{C}_{3} \mathrm{H}_{8}\right]_{\text {out }}$, are the inlet and outlet concentrations $(v / v)$ of $\mathrm{C}_{3} \mathrm{H}_{8}$, respectively, $\mathrm{F}_{\text {in }}$ and $\mathrm{F}_{\text {out }}$ are the total flow rates in the inlet and outlet of the reactor $\left(\mathrm{mols}^{-1}\right)$, respectively, and $\mathrm{W}$ is the mass of catalyst ( $\left.g_{\text {cat }}\right)$.

Turnover frequencies (TOFs) of propane conversion were estimated following Equation (8) taking into account the measurements of both the reaction rates and nickel dispersions:

$$
\mathrm{TOF}=\frac{\mathrm{R}_{\mathrm{C}_{8} \mathrm{H}_{8}} \cdot \mathrm{AW}}{\mathrm{D}_{\mathrm{Ni}} \cdot \mathrm{X}_{\mathrm{Ni}}}
$$

where $\mathrm{AW}_{\mathrm{Ni}}$ is the atomic weight of nickel $\left(\mathrm{g}_{\mathrm{Ni}} / \mathrm{mol}_{\mathrm{Ni}}\right), \mathrm{X}_{\mathrm{Ni}}$ is the nickel loading $\left(\mathrm{g}_{\mathrm{Ni}} / \mathrm{g}_{\mathrm{cat}}\right)$ and $\mathrm{D}_{\mathrm{Ni}}$ is the dispersion of nickel.

\subsection{In Situ FTIR Spectroscopy}

In situ Fourier transform infrared (FTIR) experiments were carried out using an iS20 FTIR spectrometer (Nicolet, Thermo Fischer Scientific, Waltham, MA, USA) equipped with an MCT detector, a KBr beam splitter and a diffuse reflectance (DRIFT) sampling system (Specac, Orpington, UK) accompanied by an environmental chamber suitable for the study of diffusely reflecting solid samples in a controlled atmosphere. A flow system equipped with mass flow controllers, a steam saturator and a set of valves used for controlling the gas stream interacted with the catalyst surface, was directly connected to the gas inlet of the environmental chamber.

In a typical experiment, the catalyst powder was placed in the sampling system and heated at $500{ }^{\circ} \mathrm{C}$ in flowing helium for $10 \mathrm{~min}$ and then reduced under hydrogen flow at $300{ }^{\circ} \mathrm{C}$ for $30 \mathrm{~min}$. The flow was then switched to $\mathrm{He}$ and the temperature was increased at $500{ }^{\circ} \mathrm{C}$. After remaining $10 \mathrm{~min}$ at this temperature the sample was cooled at $100{ }^{\circ} \mathrm{C}$. While cooling, the background spectra were recorded at the desired temperatures. Finally, the flow was switched to the reaction mixture, which consisted of $0.5 \% \mathrm{C}_{3} \mathrm{H}_{8}+5 \% \mathrm{H}_{2} \mathrm{O}$ (in $\mathrm{He}$ ). Steam was introduced to the system via an independent He line passing through a saturator containing water maintained at $60^{\circ} \mathrm{C}$. The resulting gas mixture was fed to the DRIFT cell through stainless steel tubing maintained at $60^{\circ} \mathrm{C}$ by means of heating tapes. A 
spectrum was collected at $100{ }^{\circ} \mathrm{C}$ after $15 \mathrm{~min}$-on-stream followed by a stepwise increase of temperature up to $500{ }^{\circ} \mathrm{C}$. During heating, spectra were recorded at selected temperatures after an equilibration for $15 \mathrm{~min}$. In all experiments, the total flow through the DRIFT cell was $30 \mathrm{~cm}^{3} \mathrm{~min}^{-1}$. Reaction gases $\left(\mathrm{He}, 2 \% \mathrm{C}_{3} \mathrm{H}_{8} / \mathrm{He}, \mathrm{H}_{2}\right)$ are supplied from high-pressure gas cylinders (Buse Gas, Bad Hönningen, Germany) and are of ultrahigh purity.

\section{Results}

\subsection{Catalyst Characterization}

The XRD patterns of $\mathrm{Ni} / \mathrm{M}_{x} \mathrm{O}_{y}$ catalysts are shown in Figure 1. The characteristic peaks located at the diffraction angles of $32.7^{\circ}, 37.7^{\circ}, 39.9^{\circ}, 45.8^{\circ}$ and $67.5^{\circ}$ were appeared for $\mathrm{Ni} / \mathrm{Al}_{2} \mathrm{O}_{3}$ which are attributed to (220), (311), (222), (400) and (440) facets of cubic $\mathrm{Al}_{2} \mathrm{O}_{3}$ (JCPDS Card No. 10-425), respectively. The XRD spectra recorded for $\mathrm{Ni} / \mathrm{CeO}_{2}$ catalyst consisted of peaks located at $2 \theta=28.79^{\circ}, 33.26^{\circ}, 47.62^{\circ}, 56.34^{\circ}, 59.1^{\circ}, 69.42^{\circ}, 76.66^{\circ}, 79.11^{\circ}$ attributed to (111), (200), (220), (311), (222), (400), (331) and (420) planes of the cubic $\mathrm{CeO}_{2}$ (JCPDS Card No. 2-1306), whereas in the case of $\mathrm{Ni} / \mathrm{ZrO}_{2}$ catalyst numerous peaks were detected on the XRD pattern. In particular, the peaks detected at $24.2^{\circ}, 24.5^{\circ}, 28.5^{\circ}, 31.7^{\circ}$, $34.5^{\circ}, 35.5^{\circ}, 38.9^{\circ}, 41.0^{\circ}, 41.5^{\circ}, 45.1^{\circ}, 45.8^{\circ}, 49.5^{\circ}, 50.5^{\circ}, 54.4^{\circ}, 55.7^{\circ}, 57.5^{\circ}, 60.2^{\circ}, 62.1^{\circ}, 63.2^{\circ}$, $66.0^{\circ}, 71.6^{\circ}, 75.3^{\circ}$ correspond to $(011),(-110),(-111),(111),(002),(200),(021),(-211)$, $(-121),(112),(211),(022),(-221),(202),(013),(212),(-302),(113),(311),(-321),(-104)$, $(-140)$ planes of monoclinic $\mathrm{ZrO}_{2}$ (JCPDS Card No. 13-307). When Ni was supported on YSZ, the XRD pattern was characterized by reflections at $30.4^{\circ}, 35.1^{\circ}, 50.4^{\circ}, 59.9^{\circ}, 62.9^{\circ}$ and $74.0^{\circ}$ attributed to (111), (200), (220), (311), (222) and (400) planes of YSZ (JCPDS Card No. 82-1246), respectively.

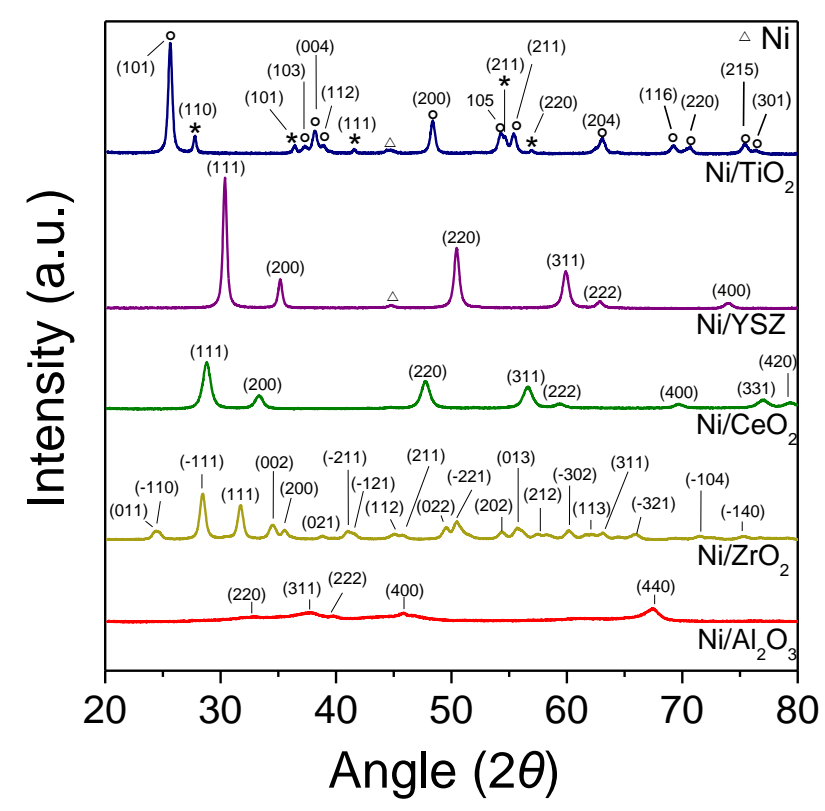

Figure 1. XRD patterns obtained from $5 \mathrm{wt} . \%$ Ni catalysts supported on the indicated commercial metal oxide carriers. The reflection planes of anatase $\left(^{\circ}\right)$ and rutile $\left(^{*}\right) \mathrm{TiO}_{2}$ phases are indicated in the diffractogram of $\mathrm{Ni} / \mathrm{TiO}_{2}$ catalyst.

Results obtained from $\mathrm{Ni} / \mathrm{TiO}_{2}$ catalyst showed that the sample consisted of $\mathrm{TiO}_{2}$ in both its anatase and rutile form exhibiting peaks at $2 \theta=25.6^{\circ}(101), 37.2^{\circ}(103), 38.2^{\circ}(004)$, $38.9^{\circ}(112), 48.4^{\circ}(200), 54.3^{\circ}(105), 55.4^{\circ}(211), 63.1^{\circ}(204), 69.3^{\circ}(116), 70.7^{\circ}(220), 75.4^{\circ}$ (215) and $76.4^{\circ}$ (301) for anatase (JCPDS Card No. 21-1272), and at $2 \theta=27.6^{\circ}(110), 36.3^{\circ}$ $(101), 41.6^{\circ}(111), 44.3^{\circ}(210), 54.6^{\circ}(211), 56.9^{\circ}(220)$ and $64.3^{\circ}(310)$ for rutile (JCPDS Card No. 21-1276).

In the case of $\mathrm{Ni} / \mathrm{TiO}_{2}$ and $\mathrm{Ni} / \mathrm{YSZ}$ catalysts an additional weak peak located $44.5^{\circ}$ was appeared corresponding to Ni (111) plane (JCPDS Card No. 04-0850). The absence of 
peaks corresponding to metallic $\mathrm{Ni}$ for the rest catalysts investigated is due to the low $\mathrm{Ni}$ loading and/or particle size. The primary crystallite size of the supports was estimated according to Scherrer's formula at the diffraction angles corresponding to (440) plane for $\mathrm{Al}_{2} \mathrm{O}_{3},(-111)$ plane for $\mathrm{ZrO}_{2}$, (111) plane for $\mathrm{CeO}_{2}$, (111) plane for YSZ and (101) plane for $\mathrm{TiO}_{2}$, and it was found to be $6.0 \mathrm{~nm}$ for Ni/ $\mathrm{Al}_{2} \mathrm{O}_{3}, 10.5 \mathrm{~nm}$ for Ni/CeO, $15.0 \mathrm{~nm}$ for $\mathrm{Ni} / \mathrm{ZrO}_{2}, 20.9 \mathrm{~nm}$ for $\mathrm{Ni} / \mathrm{YSZ}$ and $21.8 \mathrm{~nm}$ for $\mathrm{Ni} / \mathrm{TiO}_{2}$ (Table 1).

The SSAs of Ni catalysts supported on metal oxide $\left(\mathrm{M}_{x} \mathrm{O}_{y}\right)$ carriers were estimated equal to $39 \mathrm{~m}^{2} / \mathrm{g}$ for $\mathrm{Ni} / \mathrm{ZrO}_{2}, 11 \mathrm{~m}^{2} / \mathrm{g}$ for Ni/YSZ, $66 \mathrm{~m}^{2} / \mathrm{g}$ for Ni/ $\mathrm{Al}_{2} \mathrm{O}_{3}, 39 \mathrm{~m}^{2} / \mathrm{g}$ for $\mathrm{Ni} / \mathrm{CeO}_{2}$ and $41 \mathrm{~m}^{2} / \mathrm{g}$ for $\mathrm{Ni} / \mathrm{TiO}_{2}$ (Table 1 ).

Table 1. Physicochemical properties of supported Ni (5 wt.\%) catalysts and their apparent activation energies for propane steam reforming reaction.

\begin{tabular}{lccccc}
\hline Catalyst & $\mathbf{S S A}^{(\mathbf{a})}\left(\mathbf{m}^{\mathbf{2} / \mathbf{g})}\right.$ & $\begin{array}{c}\mathbf{d}_{\mathbf{M x O y}}{ }^{(\mathbf{n m})} \\
\end{array}$ & $\mathbf{D}_{\mathbf{N i}}{ }^{(\mathbf{c})} \mathbf{( \% )}$ & $\mathbf{d}_{\mathbf{N i}}{ }^{(\mathbf{c})}(\mathbf{n m})$ & $\begin{array}{c}\text { Activation } \\
\text { Energy } \\
\mathbf{( k J / m o l})\end{array}$ \\
\hline $5 \% \mathrm{Ni} / \mathrm{ZrO}_{2}$ & 39 & 15.0 & 5.7 & 17.8 & 154 \\
$5 \% \mathrm{Ni} / \mathrm{YSZ}$ & 11 & 20.9 & 4.7 & 21.4 & 140 \\
$5 \% \mathrm{Ni} / \mathrm{Al}_{2} \mathrm{O}_{3}$ & 66 & 6.0 & 4.0 & 25.5 & 121 \\
$5 \% \mathrm{Ni} / \mathrm{CeO}_{2}$ & 39 & 10.5 & 11.9 & 8.5 & 102 \\
$5 \% \mathrm{Ni} / \mathrm{TiO}_{2}$ & 41 & 21.8 & 2.8 & 36.1 & 127 \\
\hline
\end{tabular}

(a) Specific surface area, estimated with the BET method. (b) Primary crystallite size of $\mathrm{M}_{x} \mathrm{O}_{y}$, estimated from XRD line broadening. (c) Dispersion and mean particle size of $\mathrm{Ni}$, estimated from selective chemisorption measurements.

Results of Ni dispersion $\left(\mathrm{D}_{\mathrm{Ni}}\right)$ and mean particle size $\left(\mathrm{d}_{\mathrm{Ni}}\right)$ estimated from $\mathrm{CO}$ chemisorption meaurements are summarized in Table 1. Generally, low Ni dispersions were estimated for all the investigated catalysts, most possibly due to the high Ni content (5 wt.\%) in agreement with previous studies [4,6]. Higher Ni dispersion of $11.9 \%$ and smaller particle size of $8.5 \mathrm{~nm}$ was found for $\mathrm{Ni} / \mathrm{CeO}_{2}$ catalyst, whereas $\mathrm{Ni} / \mathrm{TiO}_{2}$ exhibited the lowest value of $\mathrm{Ni}$ dispersion of $2.8 \%$ and the largest particle size of $36.1 \mathrm{~nm}$.

Figure 2 shows representative TEM images and selected area electron diffraction (SAED) patterns obtained from $\mathrm{Ni} / \mathrm{YSZ}, \mathrm{Ni} / \mathrm{CeO}_{2}$ and $\mathrm{Ni} / \mathrm{TiO}_{2}$ catalysts. In all cases $\mathrm{Ni}$ particles appear as fairly homogeneously distributed spherical particles with average sizes of $20 \mathrm{~nm}$ for $\mathrm{Ni} / \mathrm{YSZ}, 10 \mathrm{~nm}$ for $\mathrm{Ni} / \mathrm{CeO}_{2}$ and $30 \mathrm{~nm}$ for $\mathrm{Ni} / \mathrm{TiO}_{2}$, in agreement with those estimated according to $\mathrm{CO}$ chemisorption measurements (Table 1 ).

(A) Ni/YSZ
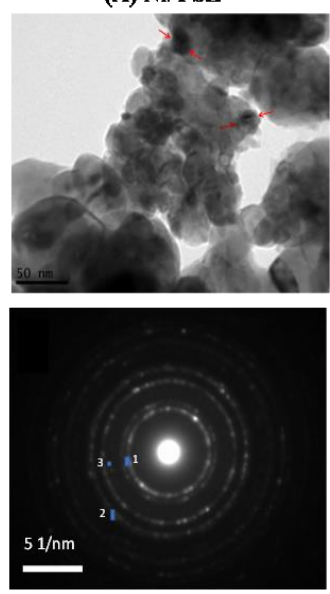

(B) $\mathrm{Ni} / \mathrm{CeO}_{2}$

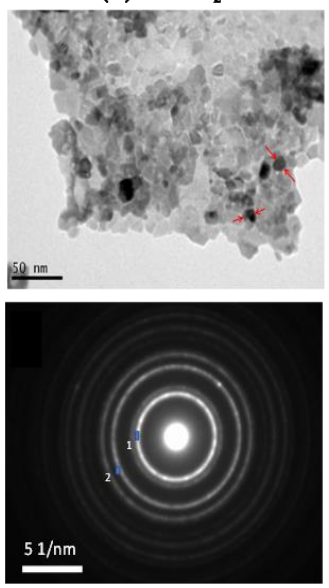

(C) $\mathrm{Ni} / \mathrm{TiO}_{2}$
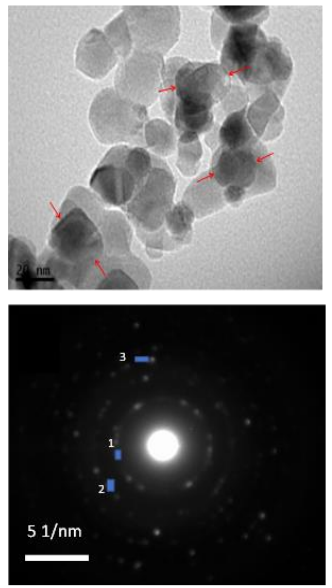

Figure 2. TEM images and Selected Area Electron Diffraction (SAED) patterns obtained for (A) $5 \% \mathrm{Ni} / \mathrm{YSZ},(\mathbf{B}) 5 \% \mathrm{Ni} / \mathrm{CeO}_{2}$ and $(\mathbf{C}) 5 \% \mathrm{Ni} / \mathrm{TiO}_{2}$ catalysts. Ni particles are indicated with red arrows. 
It should be noted that, based on the results of Table 1, the mean particle size of $\mathrm{Ni}$ is similar to the average size of the corresponding metal oxide used as support for all the investigated catalysts. This may hinder distinguishing between Ni particles and the $\mathrm{M}_{\mathrm{x}} \mathrm{O}_{\mathrm{y}}$ carrier in TEM images. Thus, SAED analysis was performed to calculate the d-spacing in an attempt to further discerned Ni particles from those of metal oxide support (Figure 2, Table 2). Results indicated that, in all cases, Ni particles are present in TEM images as evidenced by the appearance of the (111) plane of Ni $\left(d_{\text {spacing }}=0.21 \mathrm{~nm}\right.$, JCPDS No 1-1258). The appearance of the (101) $\left(\mathrm{d}_{\text {spacing }}=0.35 \mathrm{~nm}\right.$, JCPDS No 1-562) and (103) $\left(\mathrm{d}_{\text {spacing }}=0.24 \mathrm{~nm}\right.$, JCPDS No 1-562) planes of $\mathrm{TiO}_{2}$, the (111) $\left(\mathrm{d}_{\text {spacing }}=0.30 \mathrm{~nm}\right.$, JCPDS No 30-1468) and (200) ( $\mathrm{d}_{\text {spacing }}=0.26 \mathrm{~nm}$, JCPDS No 30-1468) planes of YSZ, as well as the (111) $\left(\mathrm{d}_{\text {spacing }}=0.31 \mathrm{~nm}\right.$, JCPDS No 1-800) and (200) $\left(\mathrm{d}_{\text {spacing }}=0.27 \mathrm{~nm}\right.$, JCPDS No 1-800) planes of $\mathrm{CeO}_{2}$ also confirmed the presence of the metal oxides.

Table 2. Selected area electron diffraction (SAED) analysis of TEM images obtained for 5\%Ni/YSZ, $5 \% \mathrm{Ni} / \mathrm{CeO}_{2}$ and $5 \% \mathrm{Ni} / \mathrm{TiO}_{2}$ catalysts.

\begin{tabular}{|c|c|c|c|c|c|}
\hline Catalyst & Spot & d-Spacing (Å) & Formula & $\begin{array}{l}\text { Crystallographic } \\
\text { Plane (h k l) }\end{array}$ & JCPDS No \\
\hline \multirow{3}{*}{ 5\%Ni/YSZ } & 1 & 3.0 & $\mathrm{Y}_{0.15} \mathrm{Zr}_{0.85} \mathrm{O}_{1.93}$ & $(111)$ & $30-1468$ \\
\hline & 2 & 2.6 & $\mathrm{Y}_{0.15} \mathrm{Zr}_{0.85} \mathrm{O}_{1.93}$ & $(200)$ & $30-1468$ \\
\hline & 3 & 2.1 & $\mathrm{Ni}$ & $(111)$ & $1-1258$ \\
\hline \multirow{3}{*}{$5 \% \mathrm{Ni} / \mathrm{CeO}_{2}$} & 1 & 3.1 & $\mathrm{CeO}_{2}$ & (111) & $1-800$ \\
\hline & 2 & 2.7 & $\mathrm{CeO}_{2}$ & $(200)$ & $1-800$ \\
\hline & 3 & 2.1 & $\mathrm{Ni}$ & (111) & $1-1258$ \\
\hline \multirow{3}{*}{$5 \% \mathrm{Ni} / \mathrm{TiO}_{2}$} & 1 & 3.5 & $\mathrm{TiO}_{2}$ & $(101)$ & $1-562$ \\
\hline & 2 & 2.4 & $\mathrm{TiO}_{2}$ & (103) & $1-562$ \\
\hline & 3 & 2.1 & $\mathrm{Ni}$ & (111) & $1-1258$ \\
\hline
\end{tabular}

\subsection{Influence of the Nature of the Support on Catalytic Activity}

The influence of the nature of the support on catalytic performance for the propane steam reforming reaction has been investigated using $\mathrm{Ni}$ catalysts ( $5 \mathrm{wt} . \%$ ) supported on five different commercial metal oxide powders $\left(\mathrm{ZrO}_{2}, \mathrm{YSZ}, \mathrm{TiO}_{2}, \mathrm{Al}_{2} \mathrm{O}_{3}, \mathrm{CeO}_{2}\right)$. The results obtained are shown in Figure 3A, where propane conversion is plotted as a function of reaction temperature. It is observed that, among the investigated catalysts, $\mathrm{Ni} / \mathrm{ZrO}_{2}$ is the most active one, exhibiting measurable $\mathrm{C}_{3} \mathrm{H}_{8}$ conversions at temperatures higher than $400{ }^{\circ} \mathrm{C}$ and achieving complete conversion at $750{ }^{\circ} \mathrm{C}$. Although $\mathrm{Ni} / \mathrm{YSZ}$ is activated at similar temperatures as $\mathrm{Ni} / \mathrm{ZrO}_{2}$, the conversion curve of propane is shifted toward higher temperatures. This is also the case for $\mathrm{Ni} / \mathrm{Al}_{2} \mathrm{O}_{3}$ and $\mathrm{Ni} / \mathrm{CeO}_{2}$ catalysts, which present similar performance. The latter catalysts are less active than Ni/YSZ below $550^{\circ} \mathrm{C}$, but are able to reach higher $\mathrm{X}_{\mathrm{C} 3 \mathrm{H} 8}$ at higher temperatures. The titania-supported catalyst becomes active above $500^{\circ} \mathrm{C}$, with the propane conversion curve being shifted at remarkably higher temperatures. In all examined cases, the carbon balance was satisfactory, with a deviation of $<1 \%$.

Results of specific reaction rate measurements are presented in the Arrhenius diagram of Figure 3B, where it is observed that the TOF of propane conversion increases in the order $\mathrm{Ni} / \mathrm{TiO}_{2}<\mathrm{Ni} / \mathrm{CeO}_{2}<\mathrm{Ni} / \mathrm{Al}_{2} \mathrm{O}_{3}<\mathrm{Ni} / \mathrm{YSZ}<\mathrm{Ni} / \mathrm{ZrO}_{2}$, with its value at $450{ }^{\circ} \mathrm{C}$ being more than one order of magnitude higher when $\mathrm{Ni}$ is dispersed on $\mathrm{ZrO}_{2}$ compared to $\mathrm{TiO}_{2}$, and approximately 2.5 times higher than that of $\mathrm{Ni} / \mathrm{Al}_{2} \mathrm{O}_{3}$. It should be mentioned that, as discussed above, the mean particle size of $\mathrm{Ni}$ varies significantly for the investigated catalysts from $8.5 \mathrm{~nm}$ for $\mathrm{Ni} / \mathrm{CeO}_{2}$ to $36.1 \mathrm{~nm}$ for $\mathrm{Ni} / \mathrm{TiO}_{2}$. If the $\mathrm{Ni}$ particle size were similar for this set of catalysts then the order of catalytic activity could be somewhat different. Interestingly, no trend was observed between the specific reaction rate and Ni particle size or $\mathrm{M}_{\mathrm{x}} \mathrm{O}_{\mathrm{y}}$ crystallite size or $\mathrm{M}_{\mathrm{x}} \mathrm{O}_{\mathrm{y}}$ surface area. This indicates that either 
these parameters do not affect catalytic activity or most possibly each of them contributes in a different manner to the reaction rate, resulting in the observed catalyst ranking. It should be noted that all catalysts have been reduced at $400{ }^{\circ} \mathrm{C}$ prior to physicochemical characterization measurements. Although the values of SSA or $\mathrm{d}_{\mathrm{MxOy}}$ or $\mathrm{d}_{\mathrm{Ni}}$ may were different if catalyst pre-reduction was carried out at $750{ }^{\circ} \mathrm{C}$, which is the onset reaction temperature for catalytic performance experiments, the trend of catalytic properties with respect to the nature of the support is not expected to vary due to the catalyst pretreatment at different temperatures, at least to such an extent that would affect the catalyst ranking for the propane steam reforming reaction.
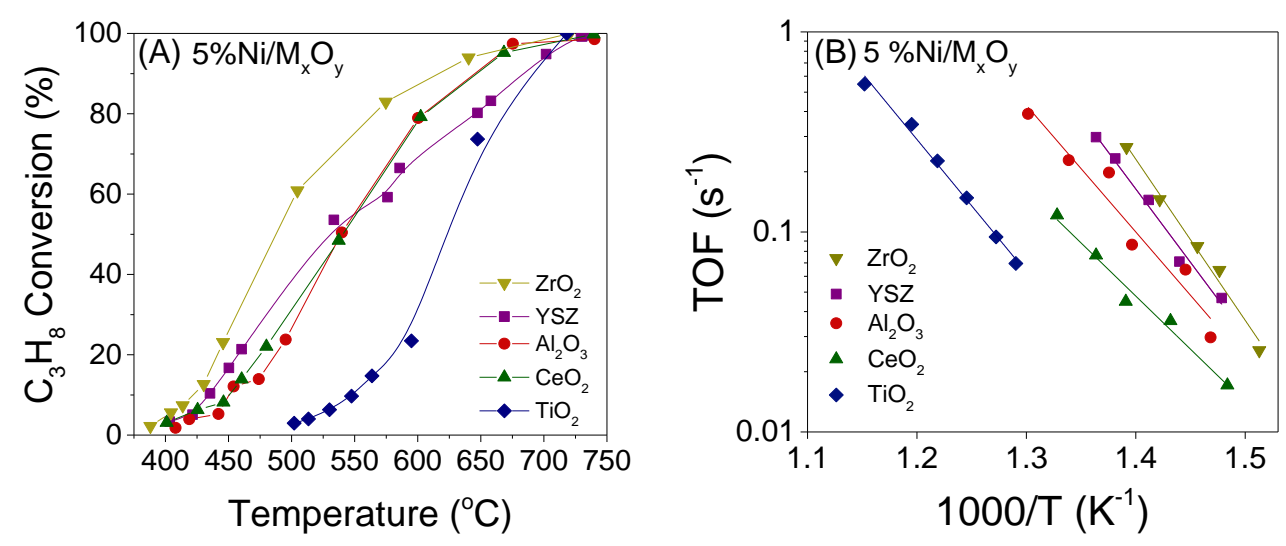

Figure 3. (A) Conversions of $\mathrm{C}_{3} \mathrm{H}_{8}$ as a function of reaction temperature and (B) Arrhenius plots of turnover frequencies of $\mathrm{C}_{3} \mathrm{H}_{8}$ conversion obtained over $\mathrm{Ni}$ catalysts (5.0 wt.\%) supported on the indicated commercial oxide carriers. Experimental conditions: Mass of catalyst: $150 \mathrm{mg}$; particle diameter: $0.15<\mathrm{d}_{\mathrm{p}}<0.25 \mathrm{~mm}$; Feed composition: $4.5 \% \mathrm{C}_{3} \mathrm{H}_{8}, 0.15 \% \mathrm{Ar}, 44 \% \mathrm{H}_{2} \mathrm{O}$ (balance He); Total flow rate: $250 \mathrm{~cm}^{3} \mathrm{~min}^{-1}$.

The apparent activation energies $\left(\mathrm{E}_{\mathrm{a}}\right)$ of the propane steam reforming reaction were calculated from the slopes of the fitted lines of Figure 3B. The results showed that the nature of the metal oxide carrier significantly affects $E_{a}$, which takes values between $102 \mathrm{~kJ} / \mathrm{mol}$ for $\mathrm{Ni} / \mathrm{CeO}_{2}$ and $154 \mathrm{~kJ} / \mathrm{mol}$ for $\mathrm{Ni} / \mathrm{ZrO}_{2}$ without presenting any trend with respect to catalytic activity (Table 1). This can be explained taking into account that, as it will be discussed below, several reactions run in parallel under the present experimental conditions each one of which is influenced by the nature of the support in a different manner resulting in the observed random variation of $E_{a}$ with catalytic activity. The results are in agreement with our previous study where it was found that the apparent activation energy for the reaction of steam reforming of propane over Rh catalysts supported on a variety of metal oxides does not present any trend with the activity order [11].

Figure 4 shows the selectivities toward reaction products as a function of temperature over the supported $\mathrm{Ni}$ catalysts investigated. In all cases the main products detected were $\mathrm{H}_{2}, \mathrm{CO}_{2}, \mathrm{CO}$ and $\mathrm{CH}_{4}$ with their selectivities being significantly varied with temperature. In particular, for $\mathrm{Ni} / \mathrm{ZrO}_{2}$ catalyst (Figure $\left.4 \mathrm{~A}\right)$, both hydrogen $\left(S_{\mathrm{H} 2}\right)$ and $\mathrm{CO}_{2}\left(S_{\mathrm{CO} 2}\right)$ selectivities decrease from 99 to $78 \%$ and from 98 to $58 \%$, respectively, with increasing temperature in the range of $390-505{ }^{\circ} \mathrm{C}$ followed by an increase of methane selectivity $\left(S_{\mathrm{CH} 4}\right)$ up to $32.5 \%$, indicating the occurrence of $\mathrm{CO}_{2}$ methanation reactions. Carbon dioxide consumption continues with further increase of temperature above $505^{\circ} \mathrm{C}$ contrary to $S_{\mathrm{H} 2}$ which progressively increases reaching $99 \%$ at $720{ }^{\circ} \mathrm{C}$. Consumption of $\mathrm{CO}_{2}$ is followed by production of CO providing evidence that the reverse WGS (RWGS) reaction is enhanced at high temperatures. Moreover, $S_{\mathrm{CH} 4}$ decreases above $505^{\circ} \mathrm{C}$ and becomes practically zero at $720^{\circ} \mathrm{C}$, implying that the reaction of methane steam reforming occurs contributing to the observed increase of both $S_{\mathrm{H} 2}$ and $S_{\mathrm{CO}}$. It should be noted that selectivity toward reaction products containing carbon was defined as the concentration of each product containing carbon at reactor effluent over the concentration of all products containing 
carbon (5), whereas $\mathrm{S}_{\mathrm{H} 2}$ was defined as the concentration of hydrogen produced divided by the concentration of all products containing hydrogen (6). Therefore, the values of $S c_{n}$ and $S_{\mathrm{H} 2}$ cannot be correlated based on the stoichiometry of the reactions taking place under propane steam reforming conditions.
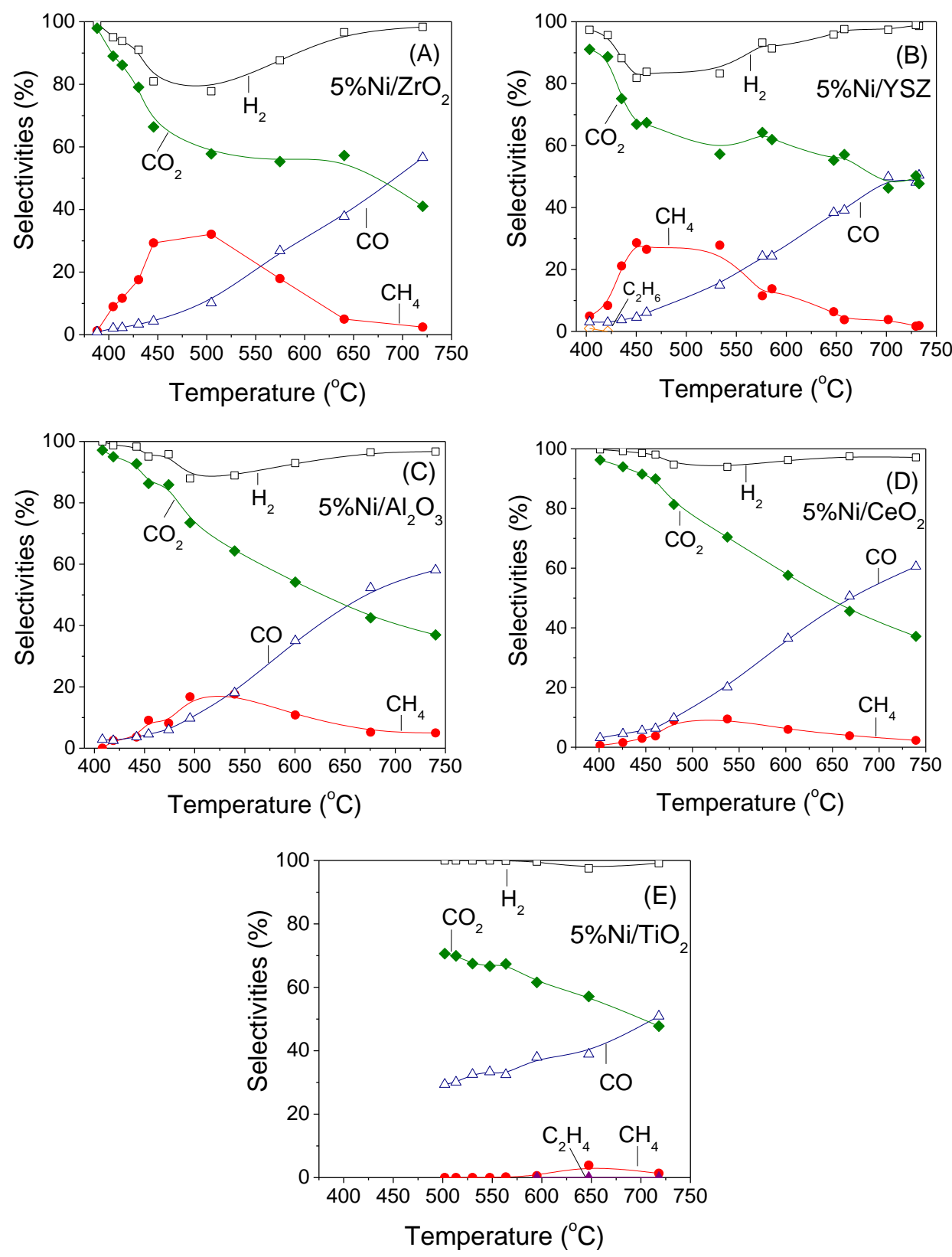

Figure 4. Selectivities toward reaction products as a function of reaction temperature obtained over Ni catalysts (5.0 wt.\%) supported on (A) $\mathrm{ZrO}_{2}$, (B) $\mathrm{YSZ}$, (C) $\mathrm{Al}_{2} \mathrm{O}_{3}$, (D) $\mathrm{CeO}_{2}$ and (E) $\mathrm{TiO}_{2}$. Experimental conditions: same as in Figure 3.

Qualitatively similar results were obtained for the rest of the investigated Ni catalysts, with the main differences being related to the values of the selectivities toward the reaction products, which reflect the extent of each reaction taking place with respect to the nature of the support. In particular, the observed decrease of $S_{\mathrm{H} 2}$ and $S_{\mathrm{CO} 2}$ at low temperatures and the simultaneous increase of $S_{\mathrm{CH} 4}$ are higher for the most active $\mathrm{Ni} / \mathrm{ZrO}_{2}$ (Figure $4 \mathrm{~A}$ ) and $\mathrm{Ni} / \mathrm{YSZ}$ (Figure $4 \mathrm{~B}$ ) catalysts, followed by Ni/ $\mathrm{Al}_{2} \mathrm{O}_{3}$ (Figure $4 \mathrm{C}$ ) and $\mathrm{Ni} / \mathrm{CeO}_{2}$ (Figure $4 \mathrm{D}$ ), whereas it is eliminated for $\mathrm{Ni} / \mathrm{TiO}_{2}$ (Figure $4 \mathrm{E}$ ). As a result methane production increases in the order of $\mathrm{Ni} / \mathrm{TiO}_{2}<\mathrm{Ni} / \mathrm{CeO}_{2}<\mathrm{Ni} / \mathrm{Al}_{2} \mathrm{O}_{3}<\mathrm{Ni} / \mathrm{YSZ}<\mathrm{Ni} / \mathrm{ZrO}_{2}$ which is consistent 
with the order of catalytic activity. This can be clearly seen in Figure 5 where the TOF at $450{ }^{\circ} \mathrm{C}$ is plotted as a function of methane selectivity obtained at the same temperature for all the investigated catalysts. It is observed that the specific reaction rate increases from $0.018 \mathrm{~s}^{-1}$ to $0.33 \mathrm{~s}^{-1}$ following the above catalyst ranking and accompanied by a parallel increase of $S_{\mathrm{CH} 4}$ from 0 to $29 \%$. The results indicate that there is a clear relationship between catalytic activity and methane production.

It should be noted that besides $\mathrm{CO}_{2}$ hydrogenation, $\mathrm{CH}_{4}$ can be also produced via $\mathrm{CO}$ hydrogenation. However, the contribution of the latter reaction does not seem to be significant for the results of the present study taking into account the low $S_{\mathrm{CO}}$ below $500{ }^{\circ} \mathrm{C}$ and its progressive increase with temperature. Moreover, methane formation may also take place via hydrogenation of $\mathrm{CH}_{x}$ species formed following the dissociative adsorption of propane on Ni surface and the subsequent hydrogenation of the so-formed $\mathrm{C}_{3} \mathrm{H}_{\mathrm{x}}$ species $[29,30]$. As it will be discussed below, the formation of $\mathrm{CH}_{\mathrm{x}}$ species intermediates may be the key reaction since it has been proposed that they interact with the hydroxyl groups or lattice oxygen of the support producing $\mathrm{CO}$ or $\mathrm{CO}_{2}$ and $\mathrm{H}_{2}[3,29,30]$.

The mass of $\mathrm{H}_{2}$ produced per propane mass unit contained in the feed was calculated at $550{ }^{\circ} \mathrm{C}$ and it was found to be higher for $\mathrm{Ni} / \mathrm{ZrO}_{2}(23.2 \mathrm{wt} . \%)$ followed by $\mathrm{Ni} / \mathrm{CeO}_{2}$ (21.2 wt.\%), $\mathrm{Ni} / \mathrm{Al}_{2} \mathrm{O}_{3}(20.6 \mathrm{wt} . \%)$ and $\mathrm{Ni} / \mathrm{YSZ}(19.7 \mathrm{wt} . \%)$, whereas $\mathrm{Ni} / \mathrm{TiO}_{2}$ exhibits the lowest $\mathrm{H}_{2}$ production (5.2 wt.\%).

The influence of the nature of the support on the activity of Ni catalysts for propane steam reforming reaction was also investigated by Harshini et al. [16], who found that $\mathrm{Ni} / \mathrm{LaAlO}_{3}$ was more active than $\mathrm{Ni} / \mathrm{Al}_{2} \mathrm{O}_{3}$, while $\mathrm{Ni} / \mathrm{CeO}_{2}$ exhibited intermediate performance. The optimum activity of the former catalyst was attributed to the small $\mathrm{Ni}$ nanoparticles dispersed on $\mathrm{LaAlO}_{3}$ surface. Although the effect of the support nature on propane steam reforming activity has not been widely studied over $\mathrm{Ni}$ catalysts, certain properties of metal oxide carriers may help explain the results of Figure 3. For example, the use of YSZ as support, which exhibited high activity in the results of the present study, has been found to suppress carbon deposition over $\mathrm{Rh}-\mathrm{Ni}$ catalysts by providing lattice oxygen, which facilitates carbon removal and enhances the dissociation of $\mathrm{C}-\mathrm{C}$ bond under reaction conditions [3]. The prevention of coke formation, occurring either via hydrocarbons decomposition or $\mathrm{CO}$ dissociation, by the lattice oxygen of the support has been also demonstrated over $\mathrm{Ni} / \mathrm{CeO}_{2}-\mathrm{Al}_{2} \mathrm{O}_{3}$ [19]. Moreover, the addition of manganese oxide on $\mathrm{Ni} / \mathrm{Al}_{2} \mathrm{O}_{3}$ was found to act as an oxygen donor that is transferred to Ni particles leading to rapid decomposition and oxidation of $\mathrm{C}_{3} \mathrm{H}_{8}$ and $\mathrm{CH}_{4}$ or $\mathrm{C}_{2} \mathrm{H}_{4}$ that may be produced under reaction conditions, resulting in further $\mathrm{H}_{2}$ production and improvement of the catalyst lifetime [9]. It has been also found that activation of steam followed by $\mathrm{H}_{2}$ formation may be favored over metal catalysts supported on "reducible" metal oxides through generation of oxygen defects, resulting in improved propane steam reforming activity and resistance to coke formation $[3,13,31]$. Based on previous studies, the reducibility of the supports used in the present study is expected to vary significantly. It is well known that $\mathrm{Al}_{2} \mathrm{O}_{3}$ is a hardly reducible metal oxide characterized by low oxygen storage capacity contrary to $\mathrm{TiO}_{2}$ and $\mathrm{CeO}_{2}$, which are strongly reducible metal oxides, or $\mathrm{ZrO}_{2}$ and $\mathrm{YSZ}$, which are characterized by intermediate oxygen mobility [32]. Based on the above, $\mathrm{Ni} / \mathrm{TiO}_{2}$ should be also active for the title reaction, taking into account that titania support is characterized by high oxygen storage capacity $[32,33]$. However, the results of Figure 3 clearly show that: (a) this catalyst was the least active one and (b) the catalytic activity is increased in the order $\mathrm{Ni} / \mathrm{TiO}_{2}<\mathrm{Ni} / \mathrm{CeO}_{2}<\mathrm{Ni} / \mathrm{Al}_{2} \mathrm{O}_{3}<\mathrm{Ni} / \mathrm{YSZ}<\mathrm{Ni} / \mathrm{ZrO}_{2}$, which cannot be correlated with the reducibility of the support. Therefore, it is evident that support reducibility is not among the key parameters affecting the catalytic activity of $\mathrm{Ni}$ according to the results of the present study. The low activity of $\mathrm{Ni} / \mathrm{TiO}_{2}$ catalyst may be related to the fact that $\mathrm{Ni} / \mathrm{TiO}_{2}$ has lower $\mathrm{Ni}$ dispersion and larger Ni particles, which was previously suggested to suppress both propane steam reforming $[15,16]$, and the intermediate $\left(\mathrm{CO}_{2}\right.$ or $\left.\mathrm{CH}_{\mathrm{x}}\right)$ hydrogenation reactions, in excellent agreement with the results of our previous study [28]. However, large $\mathrm{Ni}$ particles may not be solely responsible for the low activity of $\mathrm{Ni} / \mathrm{TiO}_{2}$ 
taking into account that no trend was observed between TOF and Ni particle size for the investigated catalysts.

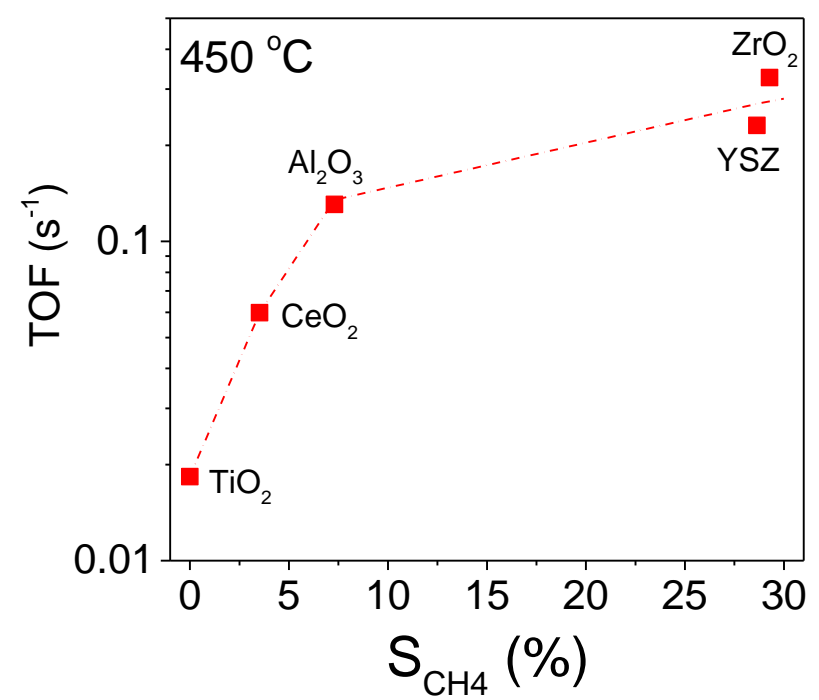

Figure 5. Turnover frequencies of $\mathrm{C}_{3} \mathrm{H}_{8}$ conversion as a function of selectivity toward $\mathrm{CH}_{4}$ obtained at $450{ }^{\circ}$ Cover supported Ni catalysts.

It should be mentioned that a different activity order was reported in our previous study over supported Rh catalysts, where it was found that $\mathrm{Rh} / \mathrm{TiO}_{2}$ was the most active catalyst with TOF being one order of magnitude higher compared to that measured for $\mathrm{Rh} / \mathrm{CeO}_{2}$ [11]. This implies that the nature of the metallic phase may affect metal/support interactions leading to variations on propane steam reforming activity and/or possibly changes on the type of active sites on the catalyst surface.

\subsection{Long Term Stability Test}

The long-term stability of $\mathrm{Ni} / \mathrm{ZrO}_{2}$ catalyst, which exhibited the highest activity, was investigated at $650{ }^{\circ} \mathrm{C}$ using the same experimental conditions as those used in catalytic performance tests. In this experiment, the catalyst was reduced in situ at $300{ }^{\circ} \mathrm{C}$ under $50 \% \mathrm{H}_{2} / \mathrm{He}$ flow followed by heating at $650{ }^{\circ} \mathrm{C}$. The flow was then switched to the reaction mixture and determination of the conversion of propane and product selectivity started. The system was shut down overnight, while the catalyst was kept at room temperature under a He flow. The next day the catalyst is heated to $650{ }^{\circ} \mathrm{C}$ in the He flow, followed by switching of the flow to the reaction mixture and determination of $\mathrm{X}_{\mathrm{C} 3 \mathrm{H} 8}$ and the product selectivity as a function of time. Results obtained are shown in Figure 6, where $X_{\mathrm{C} 3 \mathrm{H} 8}$ and $S_{\mathrm{H} 2}, S_{\mathrm{CO} 2}, S_{\mathrm{CO}}$ and $S_{\mathrm{CH} 4}$ are plotted as functions of time-on-stream. As it can be seen the catalyst presents excellent stability for more than $30 \mathrm{~h}$-on-stream. Propane conversion and hydrogen selectivity were varied in the range of $95-99 \%$ and $97-98 \%$, respectively. The selectivity toward methane was low $(3-4 \%)$ whereas $S_{\mathrm{CO}}$ and $S_{\mathrm{CO} 2}$ exhibited similar values ranging between 46 and $50 \%$. The carbon balance was found to be satisfactory during the stability test, with a deviation lower than $1-2 \%$. 


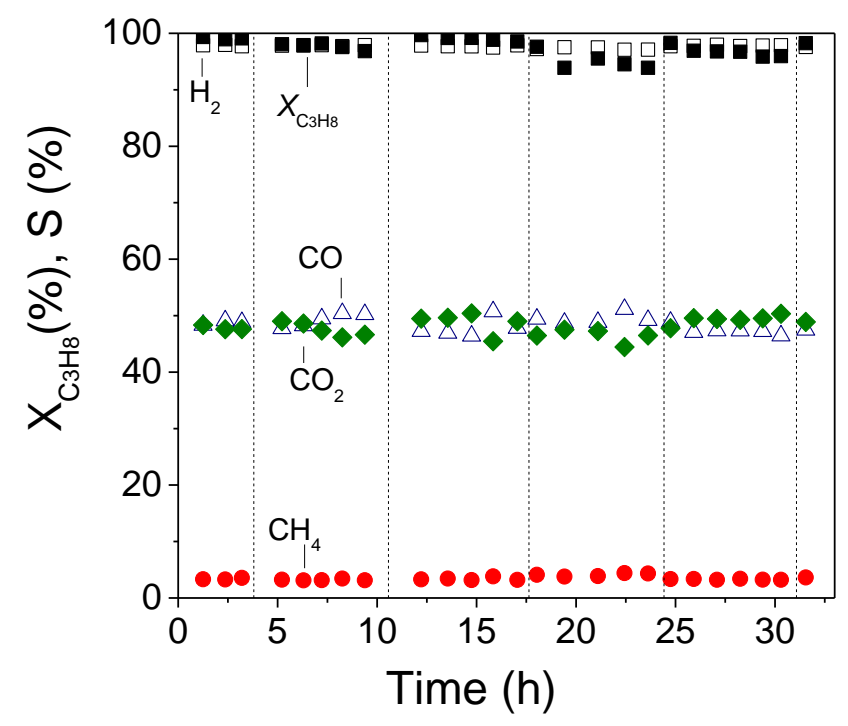

Figure 6. Long-term stability test of the $5 \% \mathrm{Ni} / \mathrm{ZrO}_{2}$ catalyst at $650{ }^{\circ} \mathrm{C}$ : Alterations of the conversion of $\mathrm{C}_{3} \mathrm{H}_{8}$ and selectivities toward reaction products with time-on-stream. Experimental conditions: Same as in Figure 3. Dashed vertical black lines indicate shutting down of the system overnight.

\subsection{DRIFT Studies}

The interaction of selected catalysts with the reaction mixture was also investigated employing in situ FTIR spectroscopy. Experiments were conducted in the temperature range of $100-500{ }^{\circ} \mathrm{C}$ using a feed composition of $0.5 \% \mathrm{C}_{3} \mathrm{H}_{8}+5 \% \mathrm{H}_{2} \mathrm{O}$ (in $\mathrm{He}$ ) and the results obtained are shown in Figure 7. It is observed that the spectrum recorded at $100{ }^{\circ} \mathrm{C}$ (Figure $7 \mathrm{~A}$, trace a) for the pre-reduced $\mathrm{Ni} / \mathrm{TiO}_{2}$ catalyst is characterized by two negative bands at 3787 and $3676 \mathrm{~cm}^{-1}$ which can be attributed to losses of $v(\mathrm{OH})$ intensity of at least two different types of free hydroxyl groups, which are either originally present on $\mathrm{TiO}_{2}$ surface or created via $\mathrm{H}_{2} \mathrm{O}$ adsorption. Two weak peaks were also detected in the $v$ (C-H) region, located at 2987 and $2966 \mathrm{~cm}^{-1}$ (trace a) due to C-H stretching vibrations in methyl groups $\left(\mathrm{CH}_{3, a d}\right)$ and to symmetric $\mathrm{C}-\mathrm{H}$ vibrations in methylene groups $\left(\mathrm{CH}_{2, \mathrm{ad}}\right)$, respectively [20,31,34-36]. These peaks are more obvious in Figure 8A (trace a) where selected spectra in the narrow range of $3200-2400 \mathrm{~cm}^{-1}$ are presented. Moreover, a band at $1642 \mathrm{~cm}^{-1}$ followed by a shoulder at $1560 \mathrm{~cm}^{-1}$ can be discerned, which have been previously assigned to carbonate species associated with $\mathrm{TiO}_{2}$ support [37-42]. An increase of temperature results in progressive separation of the latter two bands which are both shifted toward lower wavenumbers. A new band at $1430 \mathrm{~cm}^{-1}$ can be also discerned in the spectra obtained at $350{ }^{\circ} \mathrm{C}$ (trace $\mathrm{f}$ ) which is also due to carbonate species. This peak may be also present in the spectra obtained at lower temperatures but couldn't be clearly observed due to the low signal-to-noise ratio in the region below $1700 \mathrm{~cm}^{-1}$. The intensities of bands assigned to carbonate species are progressively decreased above $200{ }^{\circ} \mathrm{C}$. This decrease is accompanied by the detection of a weak peak at $2021 \mathrm{~cm}^{-1}[38,43-46]$, which is characteristic of linear-bonded $\mathrm{CO}$ on reduced nickel sites $\left(\mathrm{Ni}^{\circ}\right)$, indicating that carabonate species are further decomposed yielding $\mathrm{CO}$ and most possibly also $\mathrm{CO}_{2}$ in the gas phase. The weak bands in the $v(\mathrm{C}-\mathrm{H})$ region are present on the spectra obtained up to $500{ }^{\circ} \mathrm{C}$ (Figure 7A, trace i) implying that $\mathrm{CH}_{x}$ species are thermally stable and remained adsorbed on the catalyst surface. 

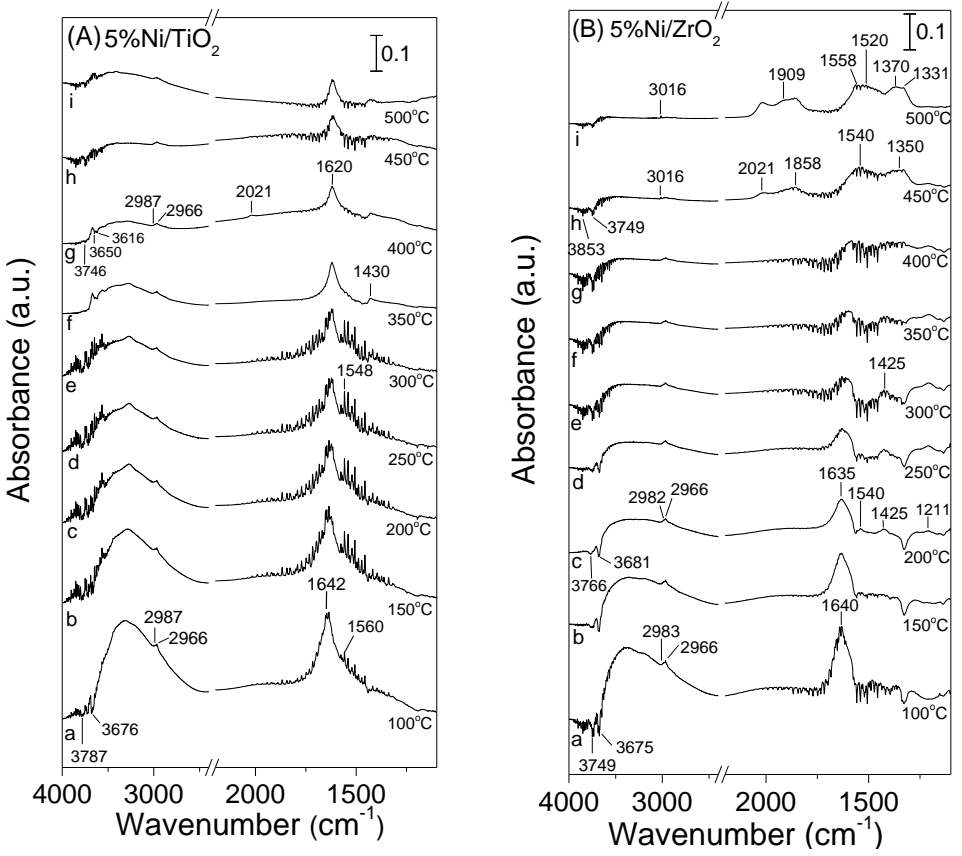

Figure 7. DRIFT spectra obtained over the $(\mathbf{A}) \mathrm{Ni} / \mathrm{TiO}_{2}$ and (B) $\mathrm{Ni} / \mathrm{ZrO}_{2}$ catalysts following interaction with $0.5 \% \mathrm{C}_{3} \mathrm{H}_{8}+5 \% \mathrm{H}_{2} \mathrm{O}$ (in $\mathrm{He}$ ) at $100{ }^{\circ} \mathrm{C}$ for $15 \mathrm{~min}$ and subsequent stepwise heating at $500{ }^{\circ} \mathrm{C}$.
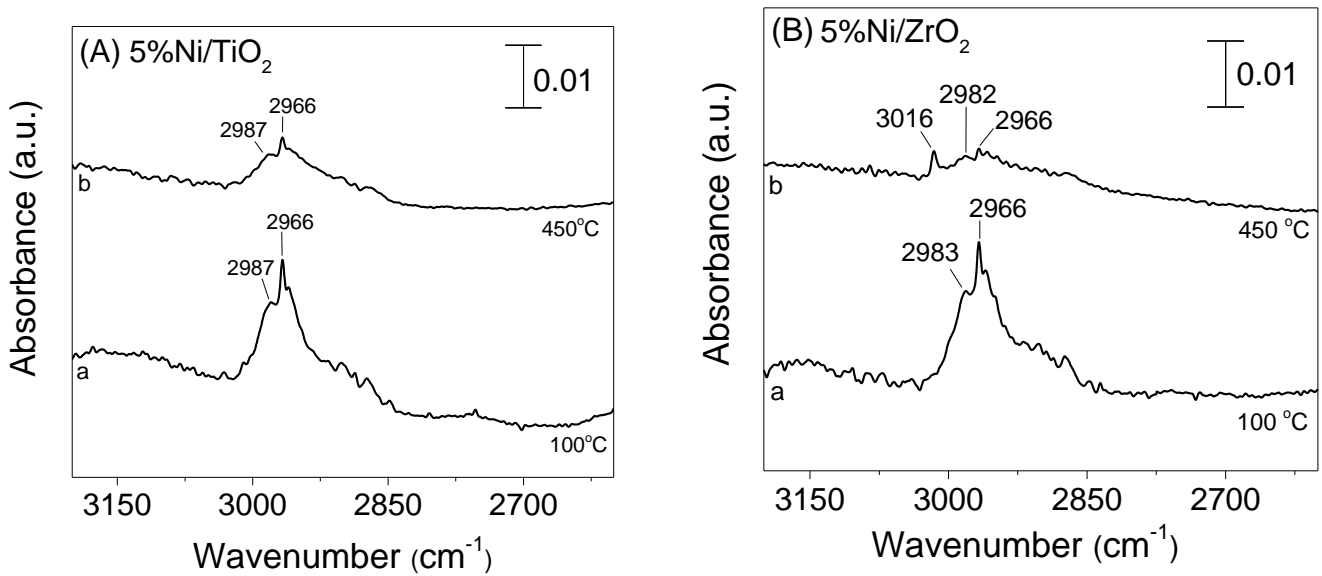

Figure 8. DRIFT spectra obtained in the region $3200-2400 \mathrm{~cm}^{-1}$ over the $(\mathbf{A}) \mathrm{Ni} / \mathrm{TiO}_{2}$ and $(\mathbf{B}) \mathrm{Ni} / \mathrm{ZrO}_{2}$ catalysts following interaction with $0.5 \% \mathrm{C}_{3} \mathrm{H}_{8}+5 \% \mathrm{H}_{2} \mathrm{O}$ (in $\mathrm{He}$ ) at $100{ }^{\circ} \mathrm{C}$ and $450{ }^{\circ} \mathrm{C}$ for $15 \mathrm{~min}$.

A similar experiment was conducted over the most active $\mathrm{Ni} / \mathrm{ZrO}_{2}$ catalyst and the results obtained are presented in Figure 7B. It is observed that the interaction of catalyst with the reformate mixture at $100{ }^{\circ} \mathrm{C}$ (trace a) results in the appearance of bands corresponding to bicarbonate species $\left(1640 \mathrm{~cm}^{-1}\right)$ [47-49], $\mathrm{CH}_{\mathrm{x}}$ species $\left(2983\right.$ and $\left.2966 \mathrm{~cm}^{-1}\right)[31,36,47]$ as well as by negative bands ( 3749 and $3675 \mathrm{~cm}^{-1}$ ) related to the consumption of surface $\mathrm{OH}$ groups $[31,36,48]$. Increase of temperature at $200^{\circ} \mathrm{C}$ (trace c) leads to the progressive development of two bands at 1540 and $1425 \mathrm{~cm}^{-1}$ due to bicarbonate species [47-49]. The intensity of the latter bands increases with increasing temperature up to $300^{\circ} \mathrm{C}$ and diminishes upon further heating at $350-400{ }^{\circ} \mathrm{C}$. This is also the case for the band at $1640 \mathrm{~cm}^{-1}$, indicating that bicarbonate species are decomposed above $450{ }^{\circ} \mathrm{C}$. At temperatures higher than $400{ }^{\circ} \mathrm{C}$ (traces h-i) two new broad bands seem to be developed at ca 1540 and $1350 \mathrm{~cm}^{-1}$. The broadness of these bands implies that they may contain contributions from more than one species with their corresponding bands being overlapped.

This can be clearly seen in the spectrum obtained at $500{ }^{\circ} \mathrm{C}$ (trace i) where four bands can be clearly discerned located at 1558, 1520, 1370 and $1331 \mathrm{~cm}^{-1}$. Those detected at 1520 
and $1331 \mathrm{~cm}^{-1}$ have been previously attributed to bidentate carbonates [49,50], whereas those located at 1558 and $1370 \mathrm{~cm}^{-1}$ can be assigned to bidentate formate species [51] adsorbed on $\mathrm{ZrO}_{2}$ surface. The appearance of the latter bands is accompanied by evolution of three peaks in the $v(\mathrm{CO})$ region due to $\mathrm{CO}$ linearly adsorbed on reduced $\mathrm{Ni}$ sites $\left(2021 \mathrm{~cm}^{-1}\right)$ and bridged bonded CO (1909 and $\left.1858 \mathrm{~cm}^{-1}\right)$ [43,46,52-54].

Interestingly, $\mathrm{CH}_{x}$ species are eliminated from the spectra obtained above $400{ }^{\circ} \mathrm{C}$ followed by evolution of $\mathrm{CH}_{4}$ in the gas phase, as evidenced by the detection of the $3016 \mathrm{~cm}^{-1}$ band (traces $\mathrm{h}-\mathrm{i}$ ). Production of $\mathrm{CH}_{4}$ at the expense of $\mathrm{CH}_{\mathrm{x}}$ species can be clearly seen in Figure $8 \mathrm{~B}$ where the spectra obtained at 100 and $450{ }^{\circ} \mathrm{C}$ in the wavenumber range of 3200-2400 $\mathrm{cm}^{-1}$ are presented.

Based on the above it can be suggested that the reaction of steam reforming of propane over $\mathrm{Ni} / \mathrm{ZrO}_{2}$ catalyst proceeds via a dissociative adsorption of propane on metallic $\mathrm{Ni}$ leading to the formation of $\mathrm{C}_{3} \mathrm{H}_{\mathrm{x}}$ species, which are further decomposed toward $\mathrm{CH}_{\mathrm{x}}$ species and probably carbon oxides due to the presence of $\mathrm{H}_{2} \mathrm{O}$ adsorbed on the support surface. This may result in the formation of the bicarbonate species $(1640,1540$ and $1425 \mathrm{~cm}^{-1}$ ) detected at low temperatures on the surface of the support [20]. Part of $\mathrm{CH}_{\mathrm{x}}$ species are hydrogenated above $400{ }^{\circ} \mathrm{C}$, yielding methane in the gas phase (band at $3016 \mathrm{~cm}^{-1}$ ) whereas the rest interact with adsorbed water producing formates (bands at 1558 and $1370 \mathrm{~cm}^{-1}$ ) and, eventually, CO species adsorbed on the Ni surface (bands at 2021, 1909 and $1858 \mathrm{~cm}^{-1}$ ). Formates may also interact with hydroxyl groups producing $\mathrm{H}_{2}$ and carbonate species (1520 and $1331 \mathrm{~cm}^{-1}$ ), which are further decomposed to $\mathrm{CO}_{2}$ [20]. It should be noted, however, that, under certain conditions, $\mathrm{CH}_{x}$ species may be also dehydrogenated producing $\mathrm{C}$ and $\mathrm{H}_{2}$. Surface carbon is either accumulated on the catalyst surface resulting in catalyst deactivation (which is not the case here) or it interacts with the hydroxyl groups or the lattice oxygen of the support yielding $\mathrm{CO}$ or $\mathrm{CO}_{2}[3,16,19,31,55]$.

The ability of $\mathrm{CH}_{x}$ species to be converted to methane and/or formates on the surface of $\mathrm{Ni} / \mathrm{ZrO}_{2}$ may imply that $\mathrm{CH}_{x}$ species are more weakly adsorbed and/or more reactive on the surface of this catalyst, thus resulting in higher overall activity for the propane steam reforming reaction. This agrees well with results of Figure 5, where it was shown that catalytic activity increases progressively with increasing methane selectivity. If as discussed above the origin of adsorbed $\mathrm{CO}$ is formate species, the high reactivity of $\mathrm{CH}_{x}$ species over $\mathrm{Ni} / \mathrm{ZrO}_{2}$ is also indirectly confirmed by the significantly higher population of carbonyl species observed over this catalyst. On the other hand, although $\mathrm{CH}_{\mathrm{x}}$ species were also detected on the surface of $\mathrm{Ni} / \mathrm{TiO}_{2}$ catalyst, no band due to gas phase methane or formate species was observed, indicating that $\mathrm{CH}_{\mathrm{x}}$ species cannot be further converted in the temperature range investigated. The increase of $\mathrm{S}_{\mathrm{CH} 4}$ in parallel with the increase of catalytic activity (Figure 5) indicates that the reactivity of $\mathrm{CH}_{\mathrm{x}}$ species is strongly related to the conversion of propane to the desired products. Although detailed mechanistic studies should be conducted to further explore the reaction pathway, it can be suggested that $\mathrm{CH}_{\mathrm{x}}$ species are key reaction intermediates for the reaction of propane steam reforming.

\section{Conclusions}

The results of the present study show that the catalytic activity of $\mathrm{Ni}$ and the product distribution for the propane steam reforming reaction depend strongly on the nature of the support. The specific reaction rate measured for $\mathrm{Ni} / \mathrm{ZrO}_{2}$ catalyst was found to be more than one order of magnitude higher compared to that measured for $\mathrm{Ni} / \mathrm{TiO}_{2}$. The intermediate production of $\mathrm{CH}_{4}$ is strongly influenced by the type of metal oxide used as support following the same trend with that of catalytic activity. DRIFTS studies provided evidences that the most active $\mathrm{Ni} / \mathrm{ZrO}_{2}$ catalyst is able to convert the intermediate produced $\mathrm{CH}_{x}$ species to $\mathrm{CH}_{4}$ and/or formate species and, subsequently, to carbon oxides and $\mathrm{H}_{2}$. In contrast, $\mathrm{CH}_{x}$ species seem to be less reactive when $\mathrm{Ni}$ is dispersed on $\mathrm{TiO}_{2}$, thus resulting in a lower reaction rate. In addition to the high activity of $\mathrm{Ni} / \mathrm{ZrO}_{2}$ catalyst, it was also found to be stable for more than $30 \mathrm{~h}$ on stream and therefore, is a promising candidate for the production of $\mathrm{H}_{2}$ for fuel cell applications. 
Author Contributions: Conceptualization, P.P.; methodology, P.P.; investigation, A.K., A.P. and P.P.; data curation, A.K., A.P. and P.P.; writing-original draft preparation, P.P.; writing-review and editing, P.P.; visualization, P.P.; supervision, P.P.; project administration, P.P.; funding acquisition, P.P. All authors have read and agreed to the published version of the manuscript.

Funding: This research has been co-financed by the European Union and Greek national funds through the Operational Program Competitiveness, Entrepreneurship and Innovation, under the call RESEARCH-CREATE-INNOVATE (project code: T1EDK-02442).

Institutional Review Board Statement: Not applicable.

Informed Consent Statement: Not applicable.

Data Availability Statement: Not applicable.

Conflicts of Interest: The authors declare no conflict of interest. The funders had no role in the design of the study; in the collection, analyses, or interpretation of data; in the writing of the manuscript, or in the decision to publish the results.

\section{References}

1. Kalamaras, C.M.; Efstathiou, A.M. Hydrogen Production Technologies: Current State and Future Developments. Conf. Pap. Energy 2013, 2013, 690627. [CrossRef]

2. Nikolaidis, P.; Poullikkas, A. A comparative overview of hydrogen production processes. Renew. Sustain. Energy Rev. 2017, 67, 597-611. [CrossRef]

3. Im, Y.; Lee, J.H.; Kwak, B.S.; Do, J.Y.; Kang, M. Effective hydrogen production from propane steam reforming using M/NiO/YSZ catalysts (M = Ru, Rh, Pd, and Ag). Catal. Today 2018, 303, 168-176. [CrossRef]

4. Santamaria, L.; Lopez, G.; Arregi, A.; Amutio, M.; Artetxe, M.; Bilbao, J.; Olazar, M. Influence of the support on Ni catalysts performance in the in-line steam reforming of biomass fast pyrolysis derived volatiles. Appl. Catal. B Environ. 2018, 229, 105-113. [CrossRef]

5. Santamaria, L.; Lopez, G.; Arregi, A.; Amutio, M.; Artetxe, M.; Bilbao, J.; Olazar, M. Stability of different Ni supported catalysts in the in-line steam reforming of biomass fast pyrolysis volatiles. Appl. Catal. B Environ. 2019, 242, 109-120. [CrossRef]

6. Miyazawa, T.; Kimura, T.; Nishikawa, J.; Kado, S.; Kunimori, K.; Tomishige, K. Catalytic performance of supported Ni catalysts in partial oxidation and steam reforming of tar derived from the pyrolysis of wood biomass. Catal. Today 2006, 115, 254-262. [CrossRef]

7. Al-Zuhair, S.; Hassan, M.; Djama, M.; Khaleel, A. Hydrogen Production by Steam Reforming of Commercially Available LPG in UAE. Chem. Eng. Commun. 2017, 204, 141-148. [CrossRef]

8. Do, J.Y.; Lee, J.H.; Park, N.-K.; Lee, T.J.; Lee, S.T.; Kang, M. Synthesis and characterization of Ni2 $-\mathrm{xPdxMnO}^{2} / \gamma-\mathrm{Al}_{2} \mathrm{O}_{3}$ catalysts for hydrogen production via propane steam reforming. Chem. Eng. J. 2018, 334, 1668-1678. [CrossRef]

9. Do, J.Y.; Park, N.-K.; Lee, T.J.; Lee, S.T.; Kang, M. Effective hydrogen productions from propane steam reforming over spinelstructured metal-manganese oxide redox couple catalysts. Int. J. Energy Res. 2018, 42, 429-446. [CrossRef]

10. Barzegari, F.; Kazemeini, M.; Farhadi, F.; Rezaei, M.; Keshavarz, A. Preparation of mesoporous nanostructure NiO-MgO-SiO2 catalysts for syngas production via propane steam reforming. Int. J. Hydrogen Energy 2020, 45, 6604-6620. [CrossRef]

11. Kokka, A.; Katsoni, A.; Yentekakis, I.V.; Panagiotopoulou, P. Hydrogen production via steam reforming of propane over supported metal catalysts. Int. J. Hydrogen Energy 2020. [CrossRef]

12. Kokka, A.; Ramantani, T.; Panagiotopoulou, P. Effect of Operating Conditions on the Performance of Rh/TiO $\mathrm{R}_{2} \mathrm{Catalyst}$ for the Reaction of LPG Steam Reforming. Catalysts 2021, 11, 374. [CrossRef]

13. Yu, L.; Sato, K.; Nagaoka, K. Rh/Ce0.25Zr0.75O2 Catalyst for Steam Reforming of Propane at Low Temperature. ChemCatChem 2019, 11, 1472-1479. [CrossRef]

14. Karakaya, C.; Karadeniz, H.; Maier, L.; Deutschmann, O. Surface Reaction Kinetics of the Oxidation and Reforming of Propane over Rh $/ \mathrm{Al}_{2} \mathrm{O}_{3}$ Catalysts. ChemCatChem 2017, 9, 685-695. [CrossRef]

15. Aghamiri, A.R.; Alavi, S.M.; Bazyari, A.; Azizzadeh Fard, A. Effects of simultaneous calcination and reduction on performance of promoted $\mathrm{Ni} / \mathrm{SiO} 2$ catalyst in steam reforming of propane. Int. J. Hydrogen Energy 2019, 44, 9307-9315. [CrossRef]

16. Harshini, D.; Yoon, C.W.; Han, J.; Yoon, S.P.; Nam, S.W.; Lim, T.-H. Catalytic Steam Reforming of Propane over Ni/LaAlO3 Catalysts: Influence of Preparation Methods and OSC on Activity and Stability. Catal. Lett. 2012, 142, 205-212. [CrossRef]

17. Azizzadeh Fard, A.; Arvaneh, R.; Alavi, S.M.; Bazyari, A.; Valaei, A. Propane steam reforming over promoted Ni-Ce/MgAl2O4 catalysts: Effects of Ce promoter on the catalyst performance using developed CCD model. Int. J. Hydrogen Energy 2019, 44, 21607-21622. [CrossRef]

18. Kim, K.M.; Kwak, B.S.; Park, N.-K.; Lee, T.J.; Lee, S.T.; Kang, M. Effective hydrogen production from propane steam reforming over bimetallic co-doped $\mathrm{NiFe} / \mathrm{Al}_{2} \mathrm{O}_{3}$ catalyst. J. Ind. Eng. Chem. 2017, 46, 324-336. [CrossRef] 
19. Laosiripojana, N.; Sangtongkitcharoen, W.; Assabumrungrat, S. Catalytic steam reforming of ethane and propane over $\mathrm{CeO}_{2}-$ doped $\mathrm{Ni} / \mathrm{Al}_{2} \mathrm{O}_{3}$ at SOFC temperature: Improvement of resistance toward carbon formation by the redox property of doping $\mathrm{CeO}_{2}$. Fuel 2006, 85, 323-332. [CrossRef]

20. Natesakhawat, S.; Oktar, O.; Ozkan, U.S. Effect of lanthanide promotion on catalytic performance of sol-gel $\mathrm{Ni} / \mathrm{Al}_{2} \mathrm{O}_{3}$ catalysts in steam reforming of propane. J. Mol. Catal. A Chem. 2005, 241, 133-146. [CrossRef]

21. Matsumura, Y.; Nakamori, T. Steam reforming of methane over nickel catalysts at low reaction temperature. Appl. Catal. A Gen. 2004, 258, 107-114. [CrossRef]

22. Guo, J.; Lou, H.; Zhao, H.; Chai, D.; Zheng, X. Dry reforming of methane over nickel catalysts supported on magnesium aluminate spinels. Appl. Catal. A Gen. 2004, 273, 75-82. [CrossRef]

23. Lee, D.S.; Min, D.J. A Kinetics of Hydrogen Reduction of Nickel Oxide at Moderate Temperature. Met. Mater. Int. 2019, 25, 982-990. [CrossRef]

24. Richardson, J.T.; Scates, R.; Twigg, M.V. X-ray diffraction study of nickel oxide reduction by hydrogen. Appl. Catal. A Gen. 2003, 246, 137-150. [CrossRef]

25. Richardson, J.T.; Scates, R.M.; Twigg, M.V. X-ray diffraction study of the hydrogen reduction of $\mathrm{NiO} / \alpha-\mathrm{Al}_{2} \mathrm{O}_{3}$ steam reforming catalysts. Appl. Catal. A Gen. 2004, 267, 35-46. [CrossRef]

26. Almasan, V.; Gaeumann, T.; Lazar, M.; Marginean, P.; Aldea, N. Hydrogen spillover effect over the oxide surfaces in supported nickel catalysts. In Studies in Surface Science and Catalysis; Froment, G.F., Waugh, K.C., Eds.; Elsevier: Amsterdam, The Netherlands, 1997; Volume 109, pp. 547-552.

27. Kramer, R.; Andre, M. Adsorption of atomic hydrogen on alumina by hydrogen spillover. J. Catal. 1979, 58, 287-295. [CrossRef]

28. Hatzisymeon, M.; Petala, A.; Panagiotopoulou, P. Carbon Dioxide Hydrogenation over Supported Ni and Ru Catalysts. Catal. Lett. 2021, 151, 888-900. [CrossRef]

29. Kolb, G.; Zapf, R.; Hessel, V.; Löwe, H. Propane steam reforming in micro-channels—results from catalyst screening and optimisation. Appl. Catal. A Gen. 2004, 277, 155-166. [CrossRef]

30. Modafferi, V.; Panzera, G.; Baglio, V.; Frusteri, F.; Antonucci, P.L. Propane reforming on Ni-Ru/GDC catalyst: H2 production for IT-SOFCs under SR and ATR conditions. Appl. Catal. A Gen. 2008, 334, 1-9. [CrossRef]

31. Malaibari, Z.O.; Croiset, E.; Amin, A.; Epling, W. Effect of interactions between Ni and Mo on catalytic properties of a bimetallic $\mathrm{Ni}-\mathrm{Mo} / \mathrm{Al}_{2} \mathrm{O}_{3}$ propane reforming catalyst. Appl. Catal. A Gen. 2015, 490, 80-92. [CrossRef]

32. Helali, Z.; Jedidi, A.; Syzgantseva, O.A.; Calatayud, M.; Minot, C. Scaling reducibility of metal oxides. Theor. Chem. Acc. 2017, 136, 100-115. [CrossRef]

33. Alphonse, P.; Ansart, F. Catalytic coatings on steel for low-temperature propane prereforming to solid oxide fuel cell (SOFC) application. J. Colloid Interface Sci. 2009, 336, 658-666. [CrossRef]

34. Panagiotopoulou, P.; Kondarides, D.I.; Verykios, X.E. Mechanistic aspects of the selective methanation of $\mathrm{CO}_{\text {over }} \mathrm{Ru} / \mathrm{TiO}_{2}$ catalyst. Catal. Today 2012, 181, 138-147. [CrossRef]

35. Panagiotopoulou, P. Methanation of $\mathrm{CO}_{2}$ over alkali-promoted $\mathrm{Ru} / \mathrm{TiO}_{2}$ catalysts: II. Effect of alkali additives on the reaction pathway. Appl. Catal. B Environ. 2018, 236, 162-170. [CrossRef]

36. Wang, B.; Wu, X.; Ran, R.; Si, Z.; Weng, D. IR characterization of propane oxidation on $\mathrm{Pt} / \mathrm{CeO}_{2}-\mathrm{ZrO}_{2}$ : The reaction mechanism and the role of Pt. J. Mol. Catal. A Chem. 2012, 356, 100-105. [CrossRef]

37. Panagiotopoulou, P.; Christodoulakis, A.; Kondarides, D.I.; Boghosian, S. Particle size effects on the reducibility of titanium dioxide and its relation to the water-gas shift activity of $\mathrm{Pt} / \mathrm{TiO}_{2}$ catalysts. J. Catal. 2006, 240, 114-125. [CrossRef]

38. Kokka, A.; Ramantani, T.; Petala, A.; Panagiotopoulou, P. Effect of the nature of the support, operating and pretreatment conditions on the catalytic performance of supported Ni catalysts for the selective methanation of CO. Catal. Today 2020, 355, 832-843. [CrossRef]

39. Karelovic, A.; Ruiz, P. Mechanistic study of low temperature $\mathrm{CO}_{2}$ methanation over $\mathrm{Rh} / \mathrm{TiO}_{2}$ catalysts. J. Catal. 2013, $301,141-153$. [CrossRef]

40. Liao, L.F.; Lien, C.F.; Shieh, D.L.; Chen, M.T.; Lin, J.L. FTIR Study of Adsorption and Photoassisted Oxygen Isotopic Exchange of Carbon Monoxide, Carbon Dioxide, Carbonate, and Formate on $\mathrm{TiO}_{2}$. J. Phys. Chem. B 2002, 106, 11240-11245. [CrossRef]

41. Marwood, M.; Doepper, R.; Renken, A. In-situ surface and gas phase analysis for kinetic studies under transient conditions The catalytic hydrogenation of CO2. Appl. Catal. A Gen. 1997, 151, 223-246. [CrossRef]

42. Mino, L.; Spoto, G.; Ferrari, A.M. CO2 Capture by $\mathrm{TiO}_{2}$ Anatase Surfaces: A Combined DFT and FTIR Study. J. Phys. Chem. C 2014, 118, 25016-25026. [CrossRef]

43. Aldana, P.A.U.; Ocampo, F.; Kobl, K.; Louis, B.; Thibault-Starzyk, F.; Daturi, M.; Bazin, P.; Thomas, S.; Roger, A.C. Catalytic CO 2 valorization into $\mathrm{CH}_{4}$ on Ni-based ceria-zirconia. Reaction mechanism by operando IR spectroscopy. Catal. Today 2013, 215, 201-207. [CrossRef]

44. Westermann, A.; Azambre, B.; Bacariza, M.C.; Graça, I.; Ribeiro, M.F.; Lopes, J.M.; Henriques, C. Insight into $\mathrm{CO}_{2}$ methanation mechanism over NiUSY zeolites: An operando IR study. Appl. Catal. B Environ. 2015, 174-175, 120-125. [CrossRef]

45. Mohamed, Z.; Dasireddy, V.D.B.C.; Singh, S.; Friedrich, H.B. The preferential oxidation of CO in hydrogen rich streams over platinum doped nickel oxide catalysts. Appl. Catal. B Environ. 2016, 180, 687-697. [CrossRef]

46. Konishcheva, M.V.; Potemkin, D.I.; Badmaev, S.D.; Snytnikov, P.V.; Paukshtis, E.A.; Sobyanin, V.A.; Parmon, V.N. On the Mechanism of $\mathrm{CO}$ and $\mathrm{CO}_{2}$ Methanation Over Ni/CeO 2 Catalysts. Top. Catal. 2016, 59, 1424-1430. [CrossRef] 


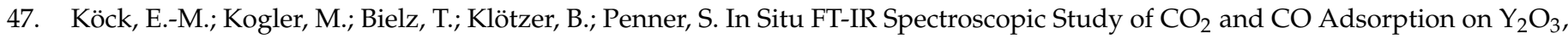
$\mathrm{ZrO}_{2}$, and Yttria-Stabilized $\mathrm{ZrO}_{2}$. J. Phys. Chem. C 2013, 117, 17666-17673. [CrossRef]

48. Bachiller-Baeza, B.; Rodriguez-Ramos, I.; Guerrero-Ruiz, A. Interaction of Carbon Dioxide with the Surface of Zirconia Polymorphs. Langmuir 1998, 14, 3556-3564. [CrossRef]

49. Zhang, Z.; Zhang, L.; Hülsey, M.J.; Yan, N. Zirconia phase effect in $\mathrm{Pd} / \mathrm{ZrO}_{2}$ catalyzed $\mathrm{CO}_{2}$ hydrogenation into formate Mol. Catal. 2019, 475, 110461. [CrossRef]

50. Föttinger, K.; Emhofer, W.; Lennon, D.; Rupprechter, G. Adsorption and Reaction of $\mathrm{CO}$ on ( $\mathrm{Pd}-) \mathrm{Al}_{2} \mathrm{O}_{3}$ and $(\mathrm{Pd}-) \mathrm{ZrO}{ }_{2}$ : Vibrational Spectroscopy of Carbonate Formation. Topics Catal. 2017, 60, 1722-1734. [CrossRef] [PubMed]

51. Pokrovski, K.; Jung, K.T.; Bell, A.T. Investigation of $\mathrm{CO}$ and $\mathrm{CO}_{2}$ Adsorption on Tetragonal and Monoclinic Zirconia. Langmuir 2001, 17, 4297-4303. [CrossRef]

52. Anderson, J.A.; Daza, L.; Fierro, J.L.G.; Rodrigo, M.T. Influence of preparation method on the characteristics of nickel/sepiolite catalysts. J. Chem. Soc. Faraday Trans. 1993, 89, 3651-3657. [CrossRef]

53. Wu, R.-f.; Zhang, Y.; Wang, Y.-z.; Gao, C.-g.; Zhao, Y.-x. Effect of $\mathrm{ZrO}_{2}$ promoter on the catalytic activity for $\mathrm{CO}$ methanation and adsorption performance of the $\mathrm{Ni} / \mathrm{SiO}_{2}$ catalyst. J. Fuel Chem. Technol. 2009, 37, 578-582. [CrossRef]

54. Zhou, G.; Liu, H.; Cui, K.; Jia, A.; Hu, G.; Jiao, Z.; Liu, Y.; Zhang, X. Role of surface $\mathrm{Ni}$ and Ce species of $\mathrm{Ni} / \mathrm{CeO}_{2}$ catalyst in $\mathrm{CO}_{2}$ methanation. Appl. Surf. Sci. 2016, 383, 248-252. [CrossRef]

55. Faria, E.C.; Rabelo-Neto, R.C.; Colman, R.C.; Ferreira, R.A.R.; Hori, C.E.; Noronha, F.B. Steam Reforming of LPG over Ni/ $\mathrm{Al}_{2} \mathrm{O}_{3}$ and $\mathrm{Ni} / \mathrm{CexZr1}-\mathrm{xO} 2 / \mathrm{Al}_{2} \mathrm{O}_{3}$ Catalysts. Catal. Lett. 2016, 146, 2229-2241. [CrossRef] 